\title{
A perspective of mesoscopic solar cells based on metal chalcogenide quantum dots and organometal-halide perovskites
}

\author{
Jae Hui Rhee, Chih-Chun Chung and Eric Wei-Guang Diau
}

We review two types of inorganic nanomaterials-metal chalcogenide quantum dots (QDs) and lead halide perovskites-that serve as prospective light harvesters in hybrid mesoscopic solar cells. Metal chalcogenide QDs are introduced in three parts: chalcogenides of cadmium ( $\mathrm{CdS}, \mathrm{CdSe}$ and $\mathrm{CdTe}$ ), chalcogenides of lead ( $\mathrm{PbS}$ and $\mathrm{PbSe}$ ) and chalcogenides of antimony $\left(\mathrm{Sb}_{2} \mathrm{~S}_{3}\right.$ and $\left.\mathrm{Sb}_{2} \mathrm{Se}_{3}\right)$. The devices made using these chalcogenide QDs in a liquid-type electrolyte showed the best cell efficiencies, ranging from 3 to $6 \%$. For solid-state QD-sensitized solar cells (QDSCs), the device performances were generally poor; only devices made of $\mathrm{Sb}_{2} \mathrm{~S}_{3}$ and $\mathrm{PbS}$ QDs attained cell efficiencies approaching $\sim 7 \%$. In contrast, nanocrystalline lead halide perovskites have emerged since 2009 as potential photosensitizers in liquid-type sensitized $\mathrm{TiO}_{2}$ solar cells. In 2012, the efficiencies of the all-solid-state perovskite solar cells were enhanced to 9.7 and $10.9 \%$ using anodes of $\mathrm{TiO}_{2}$ and $\mathrm{Al}_{2} \mathrm{O}_{3}$ films, respectively, with $2,2^{\prime}, 7,7^{\prime}$-tetrakis-( $N, N$-di-p-methoxyphenylamine) $9,9^{\prime}$-spirobifluorene (spiro-OMeTAD) as a holetransporting material. In 2013 , the performance of a $\mathrm{TiO}_{2}$ solar cell sensitized with lead iodide perovskite $\left(\mathrm{CH}_{3} \mathrm{NH}_{3} \mathrm{Pbl}_{3}\right)$ was optimized further to attain an overall power conversion efficiency $\eta=15 \%$, which is a new milestone for solar cells of this type having a device structure similar to that of a dye-sensitized solar cell.

NPG Asia Materials (2013) 5, e68; doi:10.1038/am.2013.53; published online 18 October 2013

Keywords: metal chalcogenide; perovskite; quantum dot; solar cell

\section{INTRODUCTION}

Generating cost-effective and environmentally benign renewable energy remains a major challenge for scientific development. Solar energy, which is abundant and sustainable, has attracted enormous interest in terms of research and development for many years. The developments in emerging photovoltaic techniques are taking place at a rapid pace. Most such devices involve inexpensive solution processing with high device performance. ${ }^{1-3}$ Solar cells (SCs) of these new types differ from traditional SCs in their unique mesoscopic structural features, with large surface areas that dominate their photovoltaic performance. $^{4-6}$ For example, a dye-sensitized SC (DSSC) uses a monolayer of light-absorbing sensitizer anchored on nanocrystalline $\mathrm{TiO}_{2}$ to enhance light harvesting in a mesoporous environment in which charge separation also occurs at this interface. The design of a DSSC involves an important feature: the light harvesting and charge transport are spatially decoupled. ${ }^{7}$ Since the early success of using nanocrystalline $\mathrm{TiO}_{2}$ as a charge collector, DSSCs have been considered a low-cost alternative to semiconductor-based photovoltaic devices. ${ }^{8}$ In 2011, Yeh, Diau and Grätzel developed an efficient DSSC based on an ortho-substituted porphyrin sensitizer, YD2-oC8, co-sensitized with an organic dye (Y123) with a cobalt electrolyte to attain remarkable power conversion efficiency $(\mathrm{PCE}=12.3 \%),{ }^{9}$ which opened a new research area on porphyrinsensitized SCs (PSSCs). ${ }^{10}$ However, the absorption spectrum of the YD2-oC8 system covers only the visible spectral region, 400-700 nm, and the lack of light-harvesting ability beyond $700 \mathrm{~nm}$ (near infrared) limits the PSSC from further enhancement of the device performance. Moreover, the enduring stability of PSSCs might be an issue for future commercialization. Various inorganic light absorbers with a lightharvesting capability that extends into the near-infrared region were hence sought to replace the delicate organic dyes.

Inorganic semiconductor quantum dots (QDs) have been extensively investigated as new photosensitizers or light absorbers to replace conventional organic-type sensitizers in DSSCs because of their excellent properties-tunable energy band gaps via varied and controlled size and shape of the nanocrystals, large optical absorption coefficients, large dipole moments for enhanced charge separation, and multiple exciton generation (MEG). ${ }^{11-18}$ For example, the performance of QD-sensitized SCs (QDSCs) has been significantly enhanced for $\mathrm{Sb}_{2} \mathrm{~S}_{3}$-sensitized $\mathrm{TiO}_{2}$ solar cells using a blended layer of poly[2,6-(4,4-bis(2-ethylhexyl)-4H-cyclopenta[2,1b;3,4-b']-dithiophene)-alt-4,7-(2,1,3-benzothiadiazole)] (PCPDTBT) 
and [6,6]-phenyl C61-butyric acid methyl ester (PCBM) as a holetransporting material (HTM) to attain $\eta=6.3 \% .{ }^{15}$ Hybrid passivated QDSCs using PbS colloidal QDs (CQDs) as a photosensitizer attained an efficiency of more than $7.0 \%,{ }^{13}$ and a large short-circuit photocurrent density $\left(J_{\mathrm{SC}} \sim 30 \mathrm{mAcm}^{-2}\right)$ was reported for a PbS:Hg QDSC. ${ }^{18}$ In general, using an inorganic light-harvesting material to replace a conventional organic or organometallic sensitizer has the advantage of obtaining superior device durability.

Typical semiconductor QDs have an average diameter of $1-10 \mathrm{~nm}$, which indicates that surface states or midgap trap states can be produced on the surfaces of the nanocrystals during the synthesis of the QDs via layer deposition on the photoanode of the solar cells. For mesoporous $\mathrm{TiO}_{2} / \mathrm{QD}$ solar cells, nanocrystalline QDs can be adsorbed and deposited on the surface of the $\mathrm{TiO}_{2}$ nanoparticles, but the QD coverage on the surface of the $\mathrm{TiO}_{2}$ nanoparticles may be a problem. As a result, these QDSC devices typically show a small open-circuit voltage $\left(V_{\mathrm{OC}}\right)$ and a poor fill factor $(\mathrm{FF})$ because of the charge loss at the interface of the $\mathrm{TiO}_{2} / \mathrm{QD} / \mathrm{HTM}$ layers. To increase $V_{\mathrm{OC}}$ and FF, we must decrease the charge loss in the QD layer and suppress the charge recombination in the $\mathrm{TiO}_{2} / \mathrm{QD}$ and $\mathrm{TiO}_{2} / \mathrm{HTM}$ interfaces. For this purpose, an insulating $\mathrm{Al}_{2} \mathrm{O}_{3}$ scaffold, surface passivation of QD films and interfacial engineering of buffer layers with organic and inorganic modifications have been employed to enhance the charge separation and charge transport in solar cells. ${ }^{2,13,17}$

A major advance in the development of novel inorganic sensitizers occurred in 2012: Park and Grätzel reported submicrometer thin-film solid-state solar cells attaining a PCE of $9.7 \%$ with a methyl ammonium lead-iodide perovskite sensitizer, $\mathrm{CH}_{3} \mathrm{NH}_{3} \mathrm{PbI}_{3}$, in a mesoporous $\mathrm{TiO}_{2}$ film (thickness $0.6 \mu \mathrm{m}$ ). ${ }^{12}$ This perovskite sensitizer has a band gap of $1.5 \mathrm{eV}$ with the energy levels of the conduction band $(\mathrm{CB})$ and the valence band (VB) matching well the CB of $\mathrm{TiO}_{2}$ and the highest occupied molecular orbital of HTM, respectively. At nearly the same time, Snaith and co-workers ${ }^{11}$ reported a similar perovskite, $\mathrm{CH}_{3} \mathrm{NH}_{3} \mathrm{PbI}_{2} \mathrm{Cl}$, that served as a light absorber for mesoscopic thin-film solid-state solar cells to attain a PCE of $10.9 \%$, for which the mesoporous $\mathrm{Al}_{2} \mathrm{O}_{3}$ film served as a scaffold to replace the $n$-type $\mathrm{TiO}_{2}$ electron-transporting layer. In 2013, Snaith and co-workers reported a significantly enhanced PCE of $12.3 \%$ for perovskite $\mathrm{CH}_{3} \mathrm{NH}_{3} \mathrm{PbI}_{3-x} \mathrm{Cl}_{x}$ solar cells with the same device structure based on $\mathrm{Al}_{2} \mathrm{O}_{3} .{ }^{2}$ Concurrently, Seok and co-workers ${ }^{3}$ reported the same superior PCE of $12.3 \%$ for another perovskite solar cell, $\mathrm{CH}_{3} \mathrm{NH}_{3} \mathrm{~Pb}\left(\mathrm{I}_{1-x} \mathrm{Br}_{x}\right)_{3}$, with the mesoporous $\mathrm{TiO}_{2}$-based device structure. Also in 2013, Grätzel and co-workers ${ }^{1}$ reported perovskite $\left(\mathrm{CH}_{3} \mathrm{NH}_{3} \mathrm{PbI}_{3}\right) \mathrm{TiO}_{2}$ solar cells with a PCE approaching $15 \%$, which set a new record for all-solid-state hybrid mesoscopic solar cells (HMSCs). The significant discovery of perovskites as novel photovoltaic materials has hence opened a new channel for the development of third-generation solar cells with the advantages of very high efficiency, low cost, ease of processing and considerable durability.

In this review, we summarize the recent investigations into novel inorganic materials, including both metal chalcogenide QDs and halide perovskite nanocrystals, applied as light-harvesting layers for HMSCs. Figures $1 \mathrm{a}$ and $\mathrm{b}$ are diagrams of the potential levels of various metal chalcogenide QDs and halide perovskites, respectively. Metal chalcogenide sensitizers of three types were introduced for QDSCs: they are classified as cadmium (Cd) chalcogenides, lead $(\mathrm{Pb})$ chalcogenides and antimony $(\mathrm{Sb})$ chalcogenides. The band gap energies $\left(E_{\mathrm{g}} / \mathrm{eV}\right)$ of the metal chalcogenides decreased systematically as the chalcogenides varied from sulfur (S) through
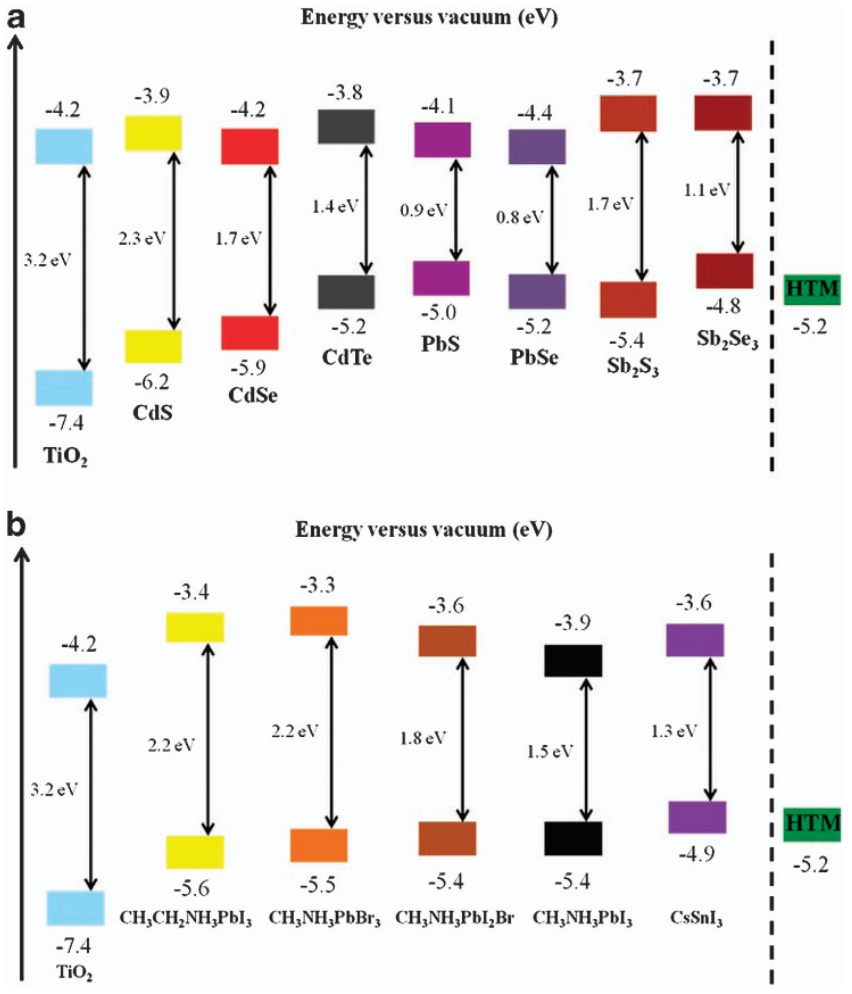

Figure 1 Energy levels vs vacuum of various (a) metal-chalcogenide quantum dots (QDs) and (b) organometal-halide perovskites as prospective light absorbers for hybrid mesoscopic solar cells. The particle sizes are shown in parentheses with the related references shown as superscripts for $\mathrm{TiO}_{2}$ (bulk), ${ }^{18} \mathrm{CdS}(5 \mathrm{~nm}),{ }^{88} \mathrm{CdSe}(3 \mathrm{~nm}),{ }^{33} \mathrm{CdTe}(3.8 \mathrm{~nm}),{ }^{33} \mathrm{PbS}$ $(2.4 \mathrm{~nm}),{ }^{18} \quad \mathrm{PbSe} \quad(4.5 \mathrm{~nm}),{ }^{48} \quad \mathrm{Sb}_{2} \mathrm{~S}_{3} \quad(5 \mathrm{~nm}),{ }^{86} \quad \mathrm{Sb}_{2} \mathrm{Se}_{3} \quad(5 \mathrm{~nm}),{ }^{99}$ $\mathrm{CH}_{3} \mathrm{CH}_{2} \mathrm{NH}_{3} \mathrm{Pbl}_{3}(1.8 \mathrm{~nm}),{ }^{102} \mathrm{CH}_{3} \mathrm{NH}_{3} \mathrm{PbBr}_{3}(7 \mathrm{~nm}),{ }^{106} \mathrm{CH}_{3} \mathrm{NH}_{3} \mathrm{Pbl}{ }_{2} \mathrm{Br}$ $(10 \mathrm{~nm}),{ }^{107} \mathrm{CH}_{3} \mathrm{NH}_{3} \mathrm{Pbl}_{3}(2.5 \mathrm{~nm})^{12}$ and $\mathrm{CsSnl}_{3}$ (bulk) ${ }^{112}$; HTM represents spiro-OMeTAD. 12

selenium (Se) to tellurium (Te). For the halide perovskite materials, tuning the band gap of $\mathrm{CH}_{3} \mathrm{NH}_{3} \mathrm{PbX}_{3}$ was achieved by varying the halide constituents $(\mathrm{X}=\mathrm{Cl}, \mathrm{Br}$ or $\mathrm{I})$; the $E_{\mathrm{g}}$ of the system decreased along this direction. This review provides detailed descriptions of the synthesis, characterization, photovoltaic performance and challenges for two inorganic materials, $\mathrm{Sb}_{2} \mathrm{~S}_{3}$ QDs and perovskite nanocrystals, because of their efficient performance as light-harvesting materials for HMSCs. We also introduce strategies for the improvement of the performances of these QD devices and perovskite materials via surface passivation and interfacial modification with varied device structures.

\section{CADMIUM CHALCOGENIDE QDSCS}

Cadmium-chalcogenide QD-based solar cells have been intensively studied over the past two decades to improve device performance and stability in ambient conditions. The photoactive sensitizers of these solar cells are composed of cadmium sulfide (CdS), ${ }^{19-25}$ cadmium selenide (CdSe), ${ }^{26-33}$ cadmium telluride (CdTe $)^{34-38}$ and their alloy nanocrystals. ${ }^{39-46} \mathrm{CdS}$ has an optical band gap of $2.25 \mathrm{eV}$, and thus it can only absorb light up to $\sim 550 \mathrm{~nm}$; CdSe, with a band gap of $1.7 \mathrm{eV}$, can absorb light below $\sim 720 \mathrm{~nm}$; CdTe has an energy gap of $1.45 \mathrm{eV}$ and an optical absorption edge at $\sim 860 \mathrm{~nm}$. The $\mathrm{CB}$ edges of CdSe and some CdTe nanocrystals were located below that of the $\mathrm{TiO}_{2}$ film (Figure 2), which resulted in poor and limited electron 
injection from the QD to the $\mathrm{TiO}_{2}$, and substantial charge recombination occurred at the $\mathrm{TiO}_{2} / \mathrm{QD} / \mathrm{HTM}$ interfaces. ${ }^{34,39}$ Moreover, the use of iodide and polysulfide electrolytes led to the degradation of these QD nanocrystals and a gradual deterioration of the photovoltaic performances. ${ }^{20,27,28,34}$

To find a solution for the above problem, co-sensitization of CdS/ CdSe QDs on $\mathrm{TiO}_{2}$ film was reported. ${ }^{39}$ The co-sensitized CdS/CdSe system showed improved light absorption, incident photon-tocurrent conversion efficiency (IPCE), and PCE over individual CdS or CdSe systems because more CdSe QDs were loaded onto the $\mathrm{TiO}_{2}$ film. The rate of electron injection from $\mathrm{CdSe}$ to $\mathrm{TiO}_{2}$ was significantly improved via the CdS layer and adjustment of the Fermi level, as shown in Figure $2 .{ }^{39} \mathrm{ZnS}$ passivation served to protect the QD sensitizers from the polysulfide electrolyte and to inhibit the charge recombination at the $\mathrm{TiO}_{2} /$ electrolyte interface. For devices made of $\mathrm{CdSe}_{x} \mathrm{Te}_{1-x}$ alloy nanocrystals, the range of optical a

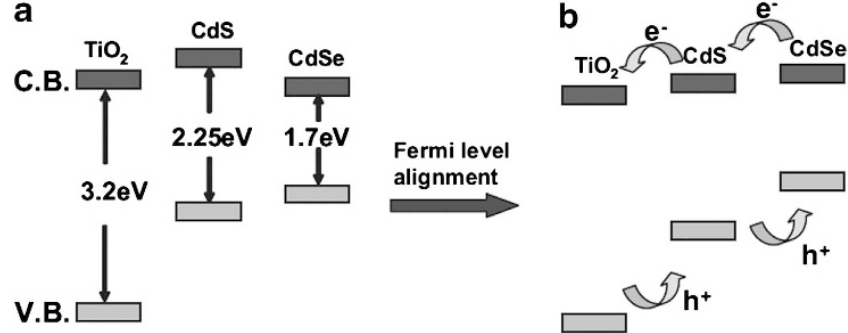

Figure 2 (a) Relative band edges of $\mathrm{TiO}_{2}, \mathrm{CdS}$ and CdSe in bulk and (b) the proposed band edge structure for a $\mathrm{TiO}_{2} / \mathrm{CdS} / \mathrm{CdSe}$ electrode after redistribution of the electrons between the CdS and CdSe interface (described as alignment of the Fermi level of bulk materials) (adapted from Lee and Lo, ${ }^{39}$ copyright 2009, Wiley-VCH Verlag GmbH \& Co.). absorption could be extended to $\sim 900 \mathrm{~nm}$, which reflects the band gap tuning effect of the CdSe-CdTe alloys, especially to enhance light harvesting in the range of 750-900 nm. Figure 3 shows the procedure used to synthesize the CdSe-CdTe QD nanocrystals by means of the layer-by-layer deposition approach, for which the optical band gaps of the alloy were systematically varied from 1.38 to $1.73 \mathrm{eV}^{40}$ Using core-shell nanocrystals, recombination losses at the $\mathrm{TiO}_{2} / \mathrm{CdTe} / \mathrm{CdSe}$ interface can be effectively diminished through a cascade potential approach that yields a superior charge separation, as shown in Figure 4. The most striking feature of this $\mathrm{CdTe} / \mathrm{CdSe}$ core-shell system, with a particle size $\sim 10 \mathrm{~nm}$, is its smaller band gap for light absorption toward the near-infrared region $(\sim 1000 \mathrm{~nm}) .{ }^{41}$ Instead of polysulfide electrolytes, quasi-solid-state polysulfide gel electrolytes, polymer electrolytes and solid-state HTM have been developed and examined for this type of QDSC, but the device efficiencies were reported to be less than $5 \% .^{20,27,28,42,43}$

The solid-state solar cells based on CdS, CdSe and CdTe QDs have shown PCEs less than $6 \%$ because of their large band gaps, slow electron injection rates and substantial charge recombination at the $\mathrm{TiO}_{2} / \mathrm{QD} / \mathrm{HTM}$ interfaces. Thin-film solar cells made of $\mathrm{CdSe}_{x} \mathrm{Te}_{1-x}$ alloys ( $x=0.9$ or 0.8$)$ exhibited a PCE $(\sim 7.1 \%)$ smaller than that of a CdTe-only device (PCE $=7.3 \%$ at $x=0$ ) because $J_{\mathrm{SC}}$ of the former is smaller than that of the latter, indicating that the electron transport and charge collection through the alloy layers encountered some difficulties in the devices. In summary, the ideal cadmium chalcogenide QDSC devices should have a large recombination resistance, a small chemical capacitance and a small series resistance due to a decreased rate of recombination and fewer trap sites at the $\mathrm{TiO}_{2} / \mathrm{QD}$ interface. Furthermore, the device performance of the CdTe/CdSe QDSCs can be further improved by increasing the QD loading on the $\mathrm{TiO}_{2}$ film to enhance the efficiency of light harvesting.

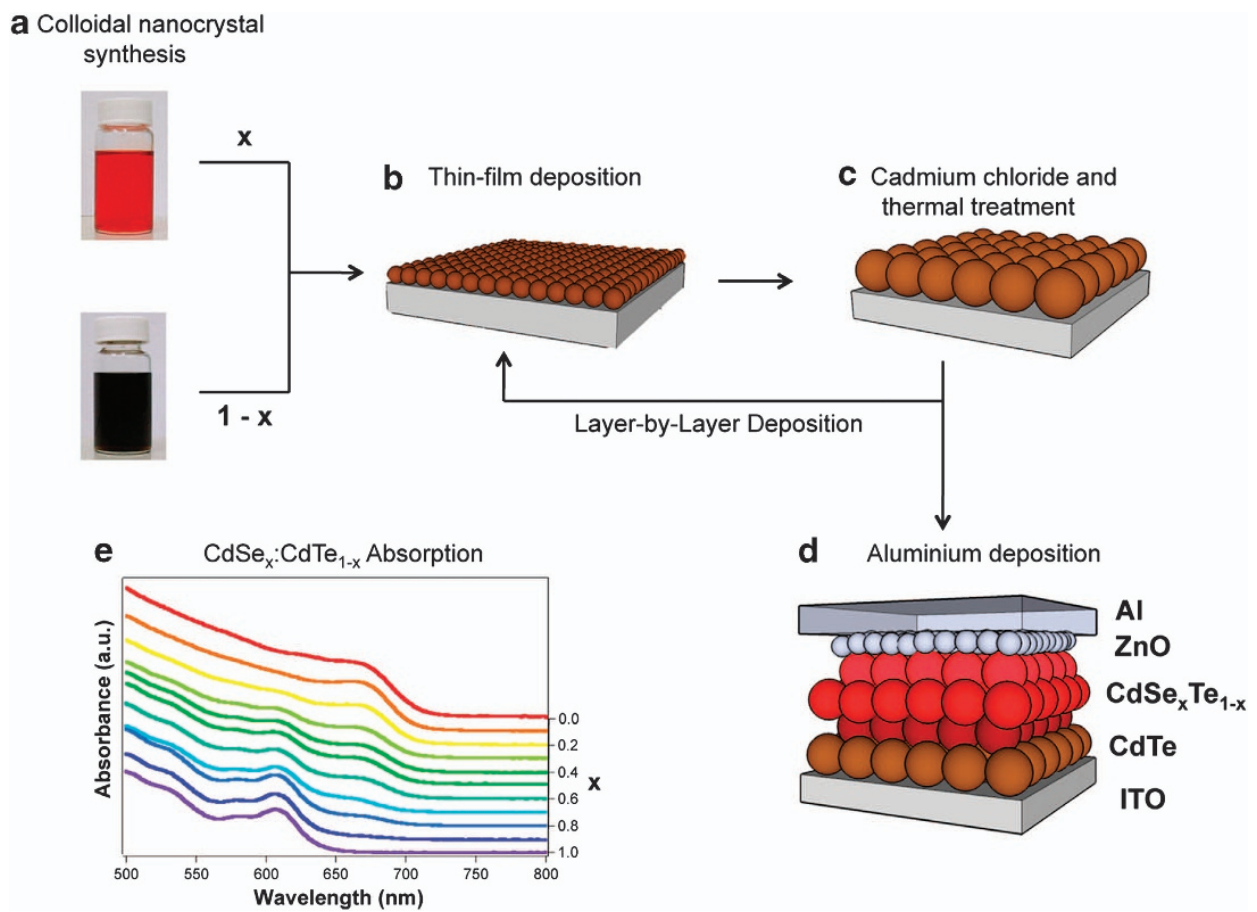

Figure 3 Schematic outline of the layer-by-layer fabrication process for $\mathrm{CdSe}_{x} \mathrm{Te}_{1-x}$ nanocrystal solar cells. (a) CdSe and CdTe nanocrystals dispersed in pyridine/1-propanol are mixed at the desired ratio. (b) A thin film of $\mathrm{CdSe}_{x}: \mathrm{CdTe}_{1-x}$ is deposited by spin coating onto the ITO substrate. (c) The thin film is subjected to treatment with $\mathrm{CdCl}_{2}$ followed by thermal annealing to promote crystal growth. This process is repeated as necessary to yield the desired device composition and active layer thickness. (d) Schematic image of a completed device, which includes a layer of nanocrystalline $\mathrm{ZnO}$ and an evaporated aluminum top contact. (e) Absorption spectra of $\mathrm{CdSe}_{x}: \mathrm{CdTe}_{1-x}$ solutions (adapted from MacDonald et al., ${ }^{40}$ copyright 2012, American Chemical Society). 


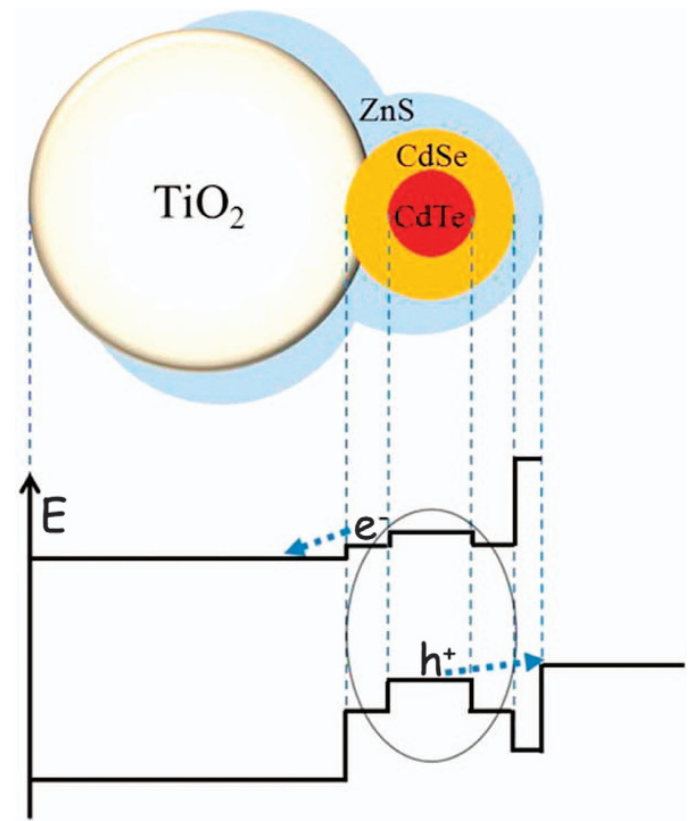

Figure 4 Schematic representation of a system consisting of a $\mathrm{CdTe} / \mathrm{CdSe}$ type-II core/shell QD adsorbed on nanocrystalline $\mathrm{TiO}_{2}$ and coated with a $\mathrm{ZnS}$ shell. An assumed band diagram of the system is also shown. Arrows show the charge directions after exciton generation (adapted from Itzhakov et al., ${ }^{41}$ copyright 2013, American Chemical Society).

\section{LEAD CHALCOGENIDE QDSCS}

Lead-chalcogenide QD-based solar cells have been intensively examined in recent years because of the small band gaps of the QDs, which allow solar energy harvesting in the near-infrared region. For example, $\mathrm{PbS}$ QDs have an energy band gap in the range of 0.9-1.1 eV, and the optical absorption edge can be extended to $\sim 1300 \mathrm{~nm} ;{ }^{13,18}$ the band gap energies of $\mathrm{PbSe} \mathrm{QDs}$ were tuned from 0.7 to $1.7 \mathrm{eV}$ by varying the sizes of the QDs, and the optical absorption edge was further extended to $\sim 1500 \mathrm{~nm} .{ }^{17,47,48}$ Under light illumination, the shunt resistance of the QDSCs was smaller than in the dark; the rates of charge recombination increased at the interfaces of QD-QD and $\mathrm{TiO}_{2}-\mathrm{QD}$ because of the increased surface states and trap states. For the PbS CQD films, a high density of midgap trap states $\left(\sim 10^{17} \mathrm{~cm}^{-3} \mathrm{eV}^{-1}\right)$ may deteriorate the device performance (Figure 5), which could be a crucial limiting factor in improving the device efficiency. ${ }^{13} \mathrm{PbSe}$ QD solar cells suffered from significant current leakage and interfacial charge recombination; the film thickness of the photoactive layer was expected to be an important parameter in optimizing the PbSe device performance. ${ }^{48}$

For $\mathrm{PbS}$ devices treated with $\mathrm{CdCl}_{2}$, the trap states near the middle of the $\mathrm{PbS}$ band gap were determined to be $\sim 10^{16} \mathrm{~cm}^{-3} \mathrm{eV}^{-1}$, which is one-fifth of that in organic cross-linked and inorganic-treated $\mathrm{PbS}$ films. ${ }^{13}$ The $\mathrm{PbS}$ film treated with $\mathrm{CdCl}_{2}$ showed the greatest hole mobility, $\mu_{\mathrm{p}}=4.2 \times 10^{-3} \mathrm{~cm}^{2} \mathrm{~V}^{-1} \mathrm{~s}^{-1}$, and $\mathrm{CdCl}_{2}$ plays a major role in the passivation of the midgap trap states and charge transport in the valence band. Greater photocurrent and voltage are achieved through decreased recombination and improved charge transport in the $\mathrm{PbS}$ device. Using $\mathrm{PbS}: \mathrm{Hg}$ nanocrystals, the short-circuit photocurrent density of the device attained $30 \mathrm{mAcm}^{-2} \cdot{ }^{18}$ The $\mathrm{CB}$ of the PbS QDs shifted upward with $\mathrm{Hg}^{2+}$ doping, and more rapid electron injection became feasible in the PbS:Hg QDSCs, as shown in Figure 6. The structural reinforcement of the $\mathrm{Pb}-\mathrm{S}$ bonds and the stability provided by the addition of $\mathrm{Hg}^{2+}$ were two major factors for the decreased charge recombination and enhanced charge transport in the $\mathrm{PbS}: \mathrm{Hg}$ device. For the hydrazine-treated PbSe QDs, the external quantum efficiency (EQE) and internal quantum efficiency (IQE) were $114 \%$ and $130 \%$, respectively, proving the MEG effect in the PbSe device shown in Figure $7 .{ }^{17}$ PbSe QDs were treated with ethane dithiol and hydrazine to increase the electronic coupling of the QD nanocrystals and decrease the surface states and trap states in the PbSe film. Approximately $1 \mathrm{mAcm}^{-2}$, or $\sim 4 \%$ of the total photocurrent, was estimated to derive from the MEG effect in the PbSe device. ${ }^{17}$

In the core-shell structure, the PbSe core was covered with a $\mathrm{PbS}$ layer (thickness $0.5 \mathrm{~nm}$ ). PbSe/PbS core-shell QDs have an absorption edge at $960 \mathrm{~nm}\left(E_{g} \sim 1.29 \mathrm{eV}\right) .{ }^{49}$ The PbS shell covering the PbSe core acted as surface passivation to protect the PbSe core, thus improving the chemical stability of the QD film. The IPCE reached $\sim 100 \%$ at $\sim 420 \mathrm{~nm}$, indicating that the core-shell QDs on the $\mathrm{TiO}_{2}$ surface had efficient light harvesting, enhanced electron injection from the QD to the $\mathrm{TiO}_{2} \mathrm{CB}$, superior charge transport in the $\mathrm{TiO}_{2}$ layer and retarded charge recombination in the QD film. For $\mathrm{PbS}_{0.9} \mathrm{Se}_{0.1}$ alloy QDSCs, an EQE above $100 \%$ at a photon energy of $2.76 \mathrm{eV}(\sim 440 \mathrm{~nm})$ was obtained. ${ }^{50} \mathrm{PbS}_{0.9} \mathrm{Se}_{0.1}$ alloy QDs showed a sharp absorption peak at $1076 \mathrm{~nm}$ due to strong quantum confinement. $\mathrm{PbS}_{0.9} \mathrm{Se}_{0.1}$ alloy QD films were treated with ethane dithiol to increase electronic coupling in the $\mathrm{PbS}_{0.9} \mathrm{Se}_{0.1}$ QDs. Greater EQE and $J_{\mathrm{SC}}$ values were obtained upon increasing the film thickness to $360 \mathrm{~nm}$ because of the increased optical absorption and higher charge generation in the device. Other $\mathrm{PbS}(\mathrm{Se}) \mathrm{QD}$ solar cells have been reported with efforts to improve the charge transport and retard the charge recombination in the devices. ${ }^{51-83}$

\section{ANTIMONY CHALCOGENIDE QDSCS}

\section{Synthesis of $\mathrm{Sb}_{2} \mathrm{~S}_{3}$ QDs on a mesoporous $\mathrm{TiO}_{2}$ film}

Antimony sulfide $\mathrm{Sb}_{2} \mathrm{~S}_{3}$ QDs have been synthesized on a mesoporous $\mathrm{TiO}_{2}$ film by means of the chemical bath deposition (CBD) method. ${ }^{14,15,84}$ Messina et al. reported a CBD procedure to form an $\mathrm{Sb}_{2} \mathrm{~S}_{3}$ thin film coating on microscope glass slides. ${ }^{84} \mathrm{SbCl}_{3}(1.3 \mathrm{~g})$ was dissolved in acetone $(5 \mathrm{ml})$; this $\mathrm{SbCl}_{3}$ solution was kept at a temperature below $4{ }^{\circ} \mathrm{C}$ for several hours. A $\mathrm{Na}_{2} \mathrm{~S}_{2} \mathrm{O}_{3}$ solution $(50 \mathrm{ml}, 1 \mathrm{M})$ and deionized water $(145 \mathrm{ml})$ were also kept at a temperature below $4{ }^{\circ} \mathrm{C}$ for several hours before the solutions were mixed. The cold $\mathrm{SbCl}_{3}$ and $\mathrm{Na}_{2} \mathrm{~S}_{2} \mathrm{O}_{3}$ solutions were mixed with continuous stirring, and the cold deionized water was added to the mixed solution. This final mixing initially gave a nearly clear solution. The substrates containing the $\mathrm{TiO}_{2}$ films were placed vertically in the $\mathrm{CBD}$ bath for $2-3 \mathrm{~h}$ in a refrigerator $\left(4-7^{\circ} \mathrm{C}\right)$. The color of the $\mathrm{Sb}_{2} \mathrm{~S}_{3}$ coated $\mathrm{TiO}_{2}$ film changed from yellow to orange-yellow and finally to brown during the CBD. Thereafter, the $\mathrm{TiO}_{2}$ films coated with $\mathrm{Sb}_{2} \mathrm{~S}_{3}$ were carefully washed with deionized water and dried at around $23^{\circ} \mathrm{C}$ for several hours in air.

As the CBD-processed $\mathrm{Sb}_{2} \mathrm{~S}_{3}$ exhibited an amorphous phase, the $\mathrm{Sb}_{2} \mathrm{~S}_{3}$-coated $\mathrm{TiO}_{2}$ films were annealed at $300-330{ }^{\circ} \mathrm{C}$ for $30 \mathrm{~min}$ under $\mathrm{Ar}$ ( or $\mathrm{N}_{2}$ ) inert conditions to form a crystalline stibnite structure. Itzhaik et al. ${ }^{85}$ reported that this annealing method, which forms an $\mathrm{Sb}_{2} \mathrm{O}_{3}$ surface passivation layer on the surface of the $\mathrm{Sb}_{2} \mathrm{~S}_{3}$ sensitizer, improved the device performance, resulting in a PCE of $3.4 \%$. This passivation layer on the $\mathrm{Sb}_{2} \mathrm{~S}_{3}$ surface can inhibit the electron-hole recombination through its insulating nature $\left(E_{\mathrm{g}} \sim 3.7 \mathrm{eV}\right.$ ), but an $\mathrm{Sb}_{2} \mathrm{O}_{3}$ layer that was thick enough to act as an energy barrier, disturbing the electron injection from the $\mathrm{Sb}_{2} \mathrm{~S}_{3}$ sensitizer to the $\mathrm{TiO}_{2}$ film, thus degrading the device performance significantly. 


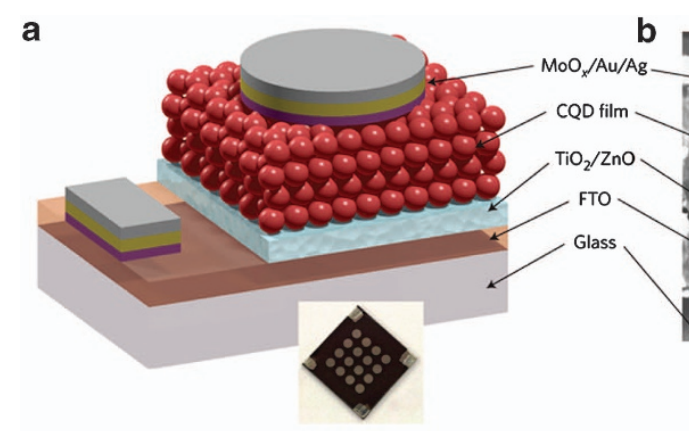

b
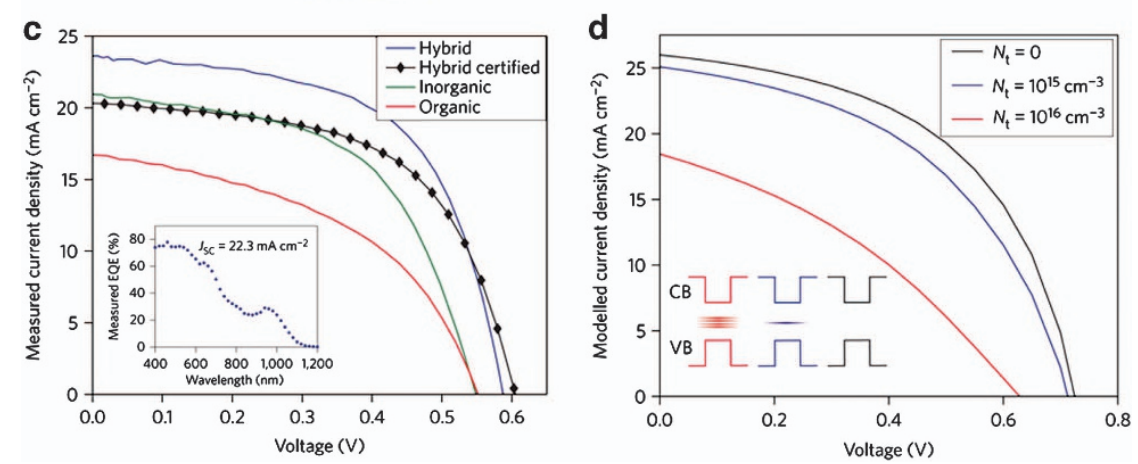

Figure 5 Performance of CQD photovoltaics as a function of passivation. (a) Schematic of the depleted heterojunction CQD device used in this work. Inset: photograph of a typical device (substrate dimensions, $25 \mathrm{~mm} \times 25 \mathrm{~mm}$ ). (b) Cross-sectional s.e.m. image of the same device. Scale bar, $500 \mathrm{~nm}$. (c) Measured current-voltage characteristics under AM1.5-simulated solar illumination for representative devices employing organic (red), inorganic (green) and hybrid (blue) passivation schemes. Black diamonds denote the $J-V$ curve for a hybrid passivated device as measured in an accredited photovoltaic calibration laboratory (Newport Technology and Application Center-PV Lab). Inset: EQE curve of a hybrid passivated device. The integrated current value is also shown. (d) Simulated $J-V$ curves of devices with varying midgap trap densities, demonstrating the detrimental effect of traps (adapted from Ip et al. ${ }^{13}$ copyright 2012, Macmillan Publishers Limited).

\section{Electronic properties of $\mathrm{Sb}_{2} \mathrm{~S}_{3}$ sensitized on $\mathrm{TiO}_{2}$ films}

Patrick and Giustino ${ }^{86}$ reported on the structural and electronic properties of $\mathrm{Sb}_{2} \mathrm{~S}_{3}$-sensitized QDSCs and found an almost perfect interface between the $\mathrm{TiO}_{2}$ film and the QD sensitizer because of the lattice match of the $\mathrm{TiO}_{2}$ substrate with the $\mathrm{Sb}_{2} \mathrm{~S}_{3}$ layer. As Figure 8 shows, no significant structural defects in the $\mathrm{TiO}_{2} / \mathrm{Sb}_{2} \mathrm{~S}_{3}$ interface were found; the electronic distributions corresponding to the $\mathrm{CB}$ of $\mathrm{Sb}_{2} \mathrm{~S}_{3}$ show a direct interfacial Ti-S coupling between $\mathrm{Sb}_{2} \mathrm{~S}_{3}$ and $\mathrm{TiO}_{2}$. The $\mathrm{CB}$ edge $\left(E_{\mathrm{CB}}\right)$ of the $\mathrm{Sb}_{2} \mathrm{~S}_{3}$ sensitizer is located $\sim 0.5 \mathrm{eV}$ above the $E_{\mathrm{CB}}$ of the $\mathrm{TiO}_{2}$ film (Figure 1a); superior electron injection from the $\mathrm{CB}$ of $\mathrm{Sb}_{2} \mathrm{~S}_{3}$ to the $\mathrm{CB}$ of $\mathrm{TiO}_{2}$ would hence be expected. For the $\mathrm{TiO}_{2} / \mathrm{Sb}_{2} \mathrm{~S}_{3}$ solar cells, the theoretical value of $V_{\mathrm{OC}}$ can be predicted to be as high as $1.6 \mathrm{~V}$, based on the calculated energy-level diagram; this value indicates that $V_{\mathrm{OC}}$ might be increased experimentally by optimizing the other parameters related to hole-transporting materials.

Optical absorption and IPCE of the $\mathrm{Sb}_{2} \mathrm{~S}_{3}$-based solar cells Crystalline $\mathrm{Sb}_{2} \mathrm{~S}_{3}$ has an optical absorption coefficient $\alpha \sim 10^{5} \mathrm{~cm}^{-1}$ in the visible region. Stibnite $\mathrm{Sb}_{2} \mathrm{~S}_{3}$ nanocrystals deposited on a mesoporous $\mathrm{TiO}_{2}$ film have a particle size of $\sim 5-10 \mathrm{~nm}$. ${ }^{14,15}$ The $\mathrm{TiO}_{2} / \mathrm{Sb}_{2} \mathrm{~S}_{3}$ system shows an excellent match of energy levels for electron injection and transport after light harvesting by the $\mathrm{Sb}_{2} \mathrm{~S}_{3}$ sensitizer. The corresponding $\mathrm{TiO}_{2} / \mathrm{Sb}_{2} \mathrm{~S}_{3}$ solar cell (SC) showed IPCE values between 70 and $90 \%$ in the visible region with various holetransporting materials, such as CuSCN, spiro-OMeTAD and poly(3hexylthiophene-2,5-diyl) (P3HT). 14,15,87-94 The IPCE curves feature an optical absorption onset at $\sim 750 \mathrm{~nm}$, which is consistent with the crystalline $\mathrm{Sb}_{2} \mathrm{~S}_{3}$ band gap of $\sim 1.65 \mathrm{eV}$. Seok and co-workers reported an IPCE loss ${ }^{15}$ in the wavelength range of $450-650 \mathrm{~nm}$, as P3HT can absorb light in this wavelength region, but the charges generated by P3HT were incompletely transferred to the Au counter electrode (CE) in the $\mathrm{TiO}_{2} / \mathrm{Sb}_{2} \mathrm{~S}_{3} / \mathrm{P} 3 \mathrm{HT}$ device. This IPCE loss was fully recovered by adding PCBM for additional conducting channels, as shown in Figure 9.

\section{Photovoltaic properties of the $\mathrm{Sb}_{2} \mathrm{~S}_{3}$-based solar cells}

Etgar and co-workers fabricated $\mathrm{Sb}_{2} \mathrm{~S}_{3} / \mathrm{P} 3 \mathrm{HT}$ solar cells with a 1-decyl phosphonic acid (DPA) surface treatment to improve the device performance. $^{94}$ Such a device attained a PCE of 3.9\%, which was significantly superior to that of a device without this surface treatment $(\eta=3.1 \%)$. The enhanced performance was due to the smaller dark current and greater electron lifetime after the DPA surface treatment. For $\mathrm{Sb}_{2} \mathrm{~S}_{3} / \mathrm{CuSCN}$ solar cells, oxygen plays an important role during the fabrication of solar cells: oxygen can decrease the series resistance of the device to enhance the overall device performance. ${ }^{87}$ It was also reported that the formation of the $\mathrm{Sb}_{2} \mathrm{O}_{3}$ surface passivation layer helps to promote the device performance. ${ }^{85}$ For the $\mathrm{Sb}_{2} \mathrm{~S}_{3}$ /spiro-OMeTAD solar cells, $J_{\mathrm{SC}}$ increased nonlinearly with increasing light intensity. ${ }^{92}$ This condition might indicate that the hole diffusion from spiroOMeTAD to the Au electrode is a bottleneck responsible for the nonlinear behavior of the photocurrents with increasing light intensity. The charge losses at higher light intensities can be decreased by improving the $\mathrm{Sb}_{2} \mathrm{~S}_{3}$ /Spiro-OMeTAD interface and using new HTM with a greater hole mobility. The highest efficiency of $\mathrm{Sb}_{2} \mathrm{~S}_{3}$-based solar cells was reported to be $6.3 \%$ using PCPDTBT as an HTM layer, giving the device a remarkable photovoltaic 

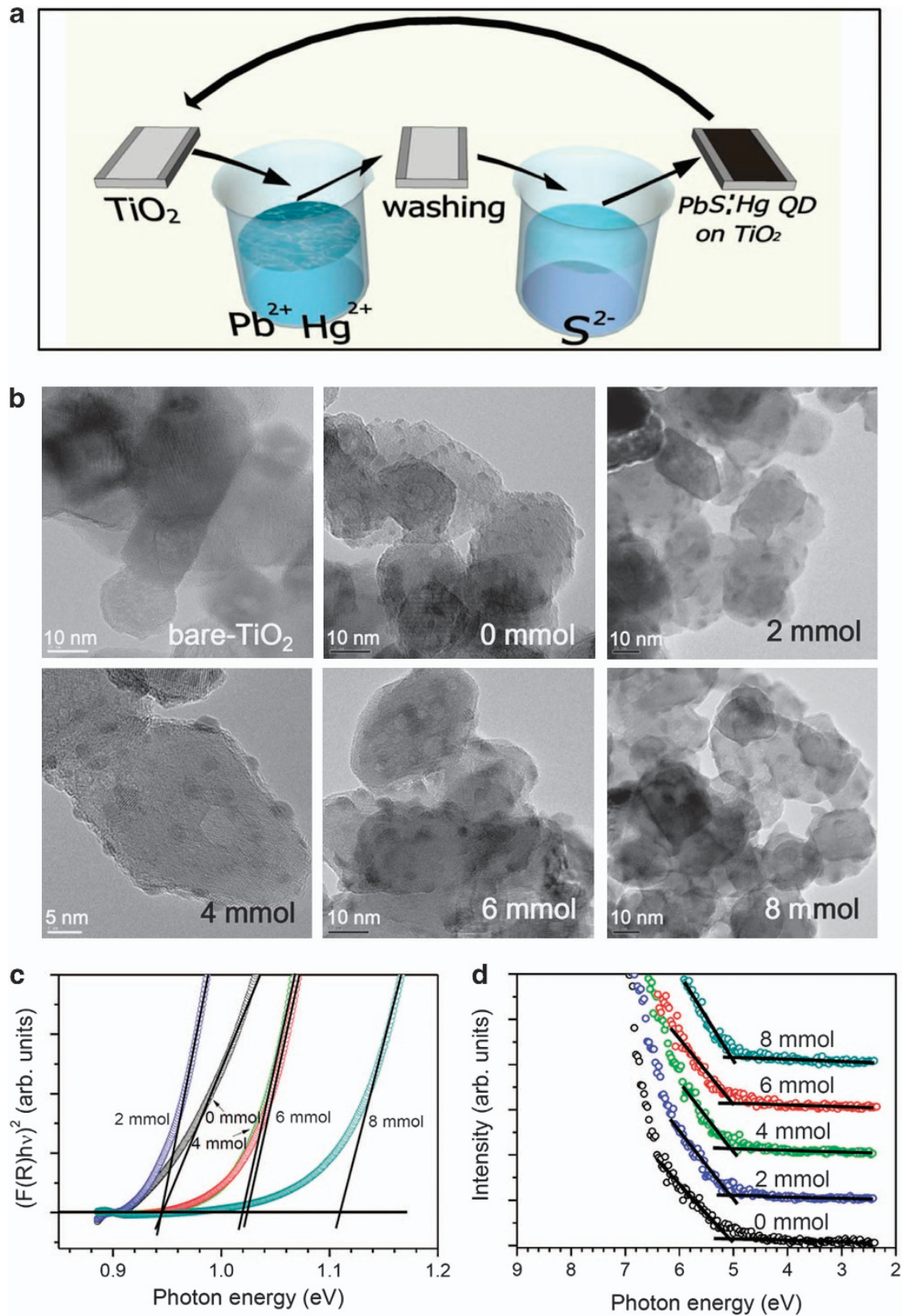

e

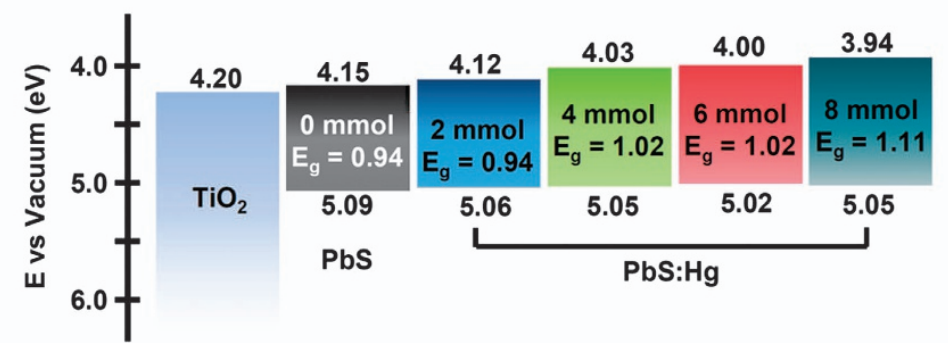

Figure 6 Morphology and energetic properties of $\mathrm{PbS}$ and $\mathrm{PbS}: \mathrm{Hg}$ QDs. (a) Deposition of a $\mathrm{PbS}: \mathrm{Hg} \mathrm{QD}$ on a mesoporous $\mathrm{TiO}_{2}$ nanostructure using successive ionic layer adsorption and reaction (SILAR). (b) TEM micrograph of bare $\mathrm{TiO}_{2}$ and $\mathrm{QD}$-coated $\mathrm{TiO}_{2}$ nanoparticles using a cationic solution containing $0,2,4,6$ and $8 \mathrm{mmol}$ of $\mathrm{HgCl}_{2}$. (c) Tauc plot calculated using the Kubelka-Munk equation from the reflectance spectra. (d) UPS spectra of $\mathrm{PbS}: \mathrm{Hg} \mathrm{QD}$-adsorbed $\mathrm{TiO}_{2}$ and extrapolation of the region of small binding energy. (e) Band edge alignment diagram of $\mathrm{PbS}$ and $\mathrm{PbS}: \mathrm{Hg} \mathrm{QD}$ (adapted from Lee et al., ${ }^{18}$ copyright 2013, Scientific Reports). 

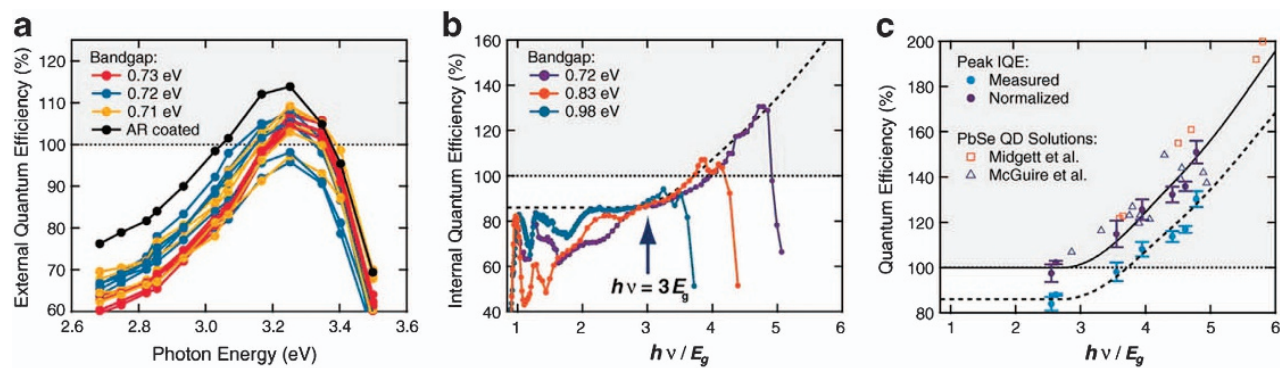

Figure 7 (a) EQE signals for 18 independent devices made with QD band gaps of $0.71 \mathrm{eV}$ (yellow), $0.72 \mathrm{eV}$ (blue) and $0.73 \mathrm{eV}$ (red) and for a device with an antireflective coating (black). (b) Collected IQE curves vs the ratio of photon energy to band gap, ho/ $E_{g}$, for the three QD sizes. The dashed curve is a published fit for colloidal QD, whereas here it has been normalized for intrinsic loss in the cell due to recombination. (c) Maximum IQE values for seven QD sizes. The peak IQE values have been corrected for the intrinsic loss in the solar cell (estimated at $\sim 15 \%$ ). Error bars indicate the propagated uncertainty of 5 to 30 measurements at the given wavelength of both the reference detector and the test solar cell. The solid black curve is the original fit to colloidal $\mathrm{QD}$; the dashed curve is the same as in (b). Hollow triangles and squares represent ultrarapid transient absorption measurements of PbSe QD solutions (adapted from Semonin et al.,17 copyright 2011, American Association for the Advancement of Science).
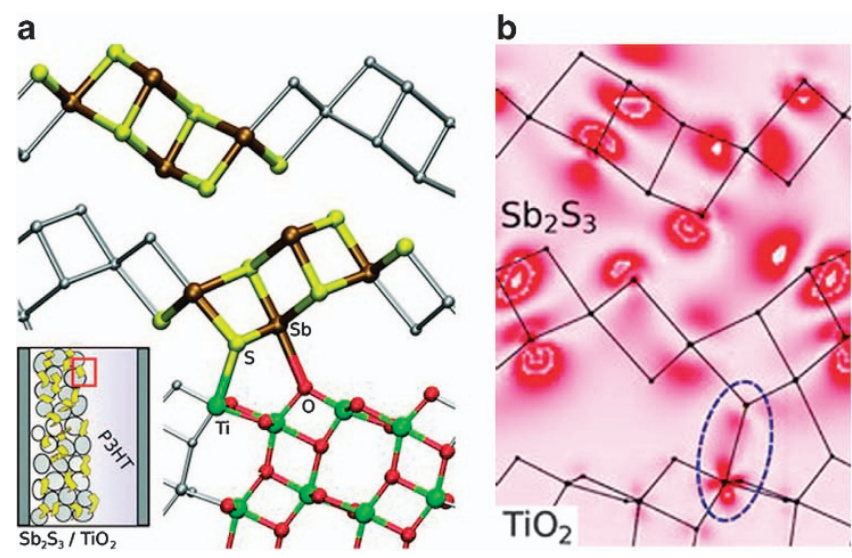

Figure 8 (a) Atomistic model of the $\mathrm{TiO}_{2} / \mathrm{Sb}_{2} \mathrm{~S}_{3}$ interface derived in this work. The colored atoms represent the periodic repeat unit; the view is along the $\mathrm{TiO}_{2}[010]$ direction. The lengths of the $\mathrm{Ti}-\mathrm{S}$ and $\mathrm{O}-\mathrm{Sb}$ bonds are 2.67 and $2.81 \AA$, respectively. Inset: Schematic representation of the stibnite-sensitized solar cell of Chang et al., with the $\mathrm{TiO}_{2} / \mathrm{Sb}_{2} \mathrm{~S}_{3}$ interface highlighted. (b) Isodensity plot of the Kohn-Sham LUMO state of $\mathrm{Sb}_{2} \mathrm{~S}_{3}$ at the $\mathrm{TiO}_{2} / \mathrm{Sb}_{2} \mathrm{~S}_{3}$ interface. The charge density is plotted in a plane through the Ti-S bond. The coupling between the S-3p states of the sensitizer and the Ti-3d states of the substrate, which provides a path for electron injection, is highlighted (adapted fromPatrick and Giustino, 86 copyright 2011, WILEY-VCH Verlag GmbH \& Co., Weinheim Germany).

performance, with $J_{\mathrm{SC}}=16.0 \mathrm{mAcm}^{-2}, \quad V_{\mathrm{OC}}=0.595 \mathrm{~V}$ and $\mathrm{FF}=0.655 .{ }^{15}$ Ito and co-workers ${ }^{89}$ reported $\mathrm{TiO}_{2} / \mathrm{Sb}_{2} \mathrm{~S}_{3} / \mathrm{CuSCN}$ solar cells with a $\mathrm{TiO}_{2}$ surface treatment $(\eta=4.1 \%)$. The $\mathrm{TiO}_{2}$ devices in which the surface was treated with $\mathrm{BaTiO}_{3} / \mathrm{MgO}$ showed much greater efficiency compared with untreated $\mathrm{TiO}_{2} / \mathrm{Sb}_{2} \mathrm{~S}_{3} / \mathrm{CuSCN}$ devices $(4.1 \%$ vs $2.8 \%)$. The $\mathrm{TiO}_{2} / \mathrm{Sb}_{2} \mathrm{~S}_{3}$ interface has been improved by a $\mathrm{BaTiO}_{3} / \mathrm{MgO}$ surface treatment; passivation of the $\mathrm{TiO}_{2}$ surface was also performed at the $\mathrm{TiO}_{2} / \mathrm{CuSCN}$ interface.

\section{Challenges in $\mathrm{Sb}_{2} \mathrm{~S}_{3}$-based solar cells}

For $\mathrm{Sb}_{2} \mathrm{~S}_{3}$-based solar cells, theoretical simulations by Bisquert and co-workers $^{88}$ have shown an optimized efficiency of $\sim 8.5 \%$ upon decreasing the series and hole-transport resistances and increasing the charge-collection efficiency. Because the electron-hole recombination occurs mostly between the electrons of the $\mathrm{CB}$ in the $\mathrm{TiO}_{2}$ layer and the holes in the HTM layer, the hole-transport properties of the HTM become important to improve the device efficiency of solar cells of this type ${ }^{88,93}$ The challenge is hence to find new HTMs with great hole mobility and stability.

Haque and co-workers recorded nanosecond transient absorption spectra (TAS) of thin film samples with a $\mathrm{TiO}_{2} / \mathrm{Sb}_{2} \mathrm{~S}_{3} /$ spiro-OMeTAD configuration. ${ }^{93}$ As Figure 10 shows, the rate of charge recombination at the $\mathrm{TiO}_{2} / \mathrm{Sb}_{2} \mathrm{~S}_{3}$ interface decreased when more successive ionic layer adsorption and reaction (SILAR) cycles were involved, making the optical onsets of the $\mathrm{Sb}_{2} \mathrm{~S}_{3}$ nanocrystals systematically red-shifted. This effect might decrease the rate of electron injection from the $\mathrm{Sb}_{2} \mathrm{~S}_{3}$ sensitizer to the $\mathrm{TiO}_{2}$ film and thus decrease the device efficiency, particularly in the wavelength region beyond $750 \mathrm{~nm}$. Hole transfer from the $\mathrm{Sb}_{2} \mathrm{~S}_{3}$ sensitizer to spiro-OMeTAD was much less sensitive to the spectral shift of the $\mathrm{Sb}_{2} \mathrm{~S}_{3}$ absorption onset, indicating that the hole transport to spiro-OMeTAD might initiate charge separation at the $\mathrm{TiO}_{2} / \mathrm{Sb}_{2} \mathrm{~S}_{3} /$ spiro-OMeTAD interface and thus improve the device performance. The same group investigated $\mathrm{Sb}_{2} \mathrm{~S}_{3} / \mathrm{P} 3 \mathrm{HT}$ films using the TAS technique. ${ }^{95}$ After excitation at $567 \mathrm{~nm}$, the $\mathrm{P} 3 \mathrm{HT}^{+}$polaron band at $950 \mathrm{~nm}$ was monitored to investigate the kinetics of hole transport and charge recombination in $\mathrm{Sb}_{2} \mathrm{~S}_{3} / \mathrm{P} 3 \mathrm{HT}$ films. According to the TAS results, the $\mathrm{P}_{3} \mathrm{HT}^{+}$polaron band was strongly dependent on the hole transfer from $\mathrm{Sb}_{2} \mathrm{~S}_{3}$ to $\mathrm{P} 3 \mathrm{HT}$, indicating that this interfacial hole transport is a key parameter for improving the device performance.

Another approach for improving the device efficiency of QDSCs is to extend the optical absorption range of the QD to $\sim 1000 \mathrm{~nm}$ to improve the light-harvesting performance of the device. The $\mathrm{Sb}_{2} \mathrm{~S}_{3}$ nanocrystals can absorb light up to $750 \mathrm{~nm}$ with an optical band gap of $\sim 1.65 \mathrm{eV}$. To further extend the optical absorption into the nearinfrared region, we must consider semiconductors with smaller band gaps, $E_{\mathrm{g}}<1.3 \mathrm{eV}$, such as $\mathrm{Sb}_{2} \mathrm{Se}_{3}$.

\section{$\mathrm{Sb}_{2} \mathrm{Se}_{3}$-sensitized solar cells}

Antimony chalcogenide semiconductor $\mathrm{Sb}_{2} \mathrm{Se}_{3}$ has an optical band gap of $1.0-1.2 \mathrm{eV}$ and shows a strong optical absorption, with a coefficient $\alpha$ of $\sim 10^{5} \mathrm{~cm}^{-1}$ in the visible region. ${ }^{84,96-98}$ Theoretical predictions for $J_{\mathrm{SC}}$ as a function of the band gap $E_{\mathrm{g}}$ give the upper limits as 22 and $43 \mathrm{mAcm}^{-2}$ for $\mathrm{Sb}_{2} \mathrm{~S}_{3}\left(E_{\mathrm{g}}=1.7 \mathrm{eV}\right)$ and $\mathrm{Sb}_{2} \mathrm{Se}_{3}$ $\left(E_{\mathrm{g}}=1.13 \mathrm{eV}\right)$ sensitizers, respectively. ${ }^{96}$ For the $\mathrm{Sb}_{2} \mathrm{Se}_{3}$-based 

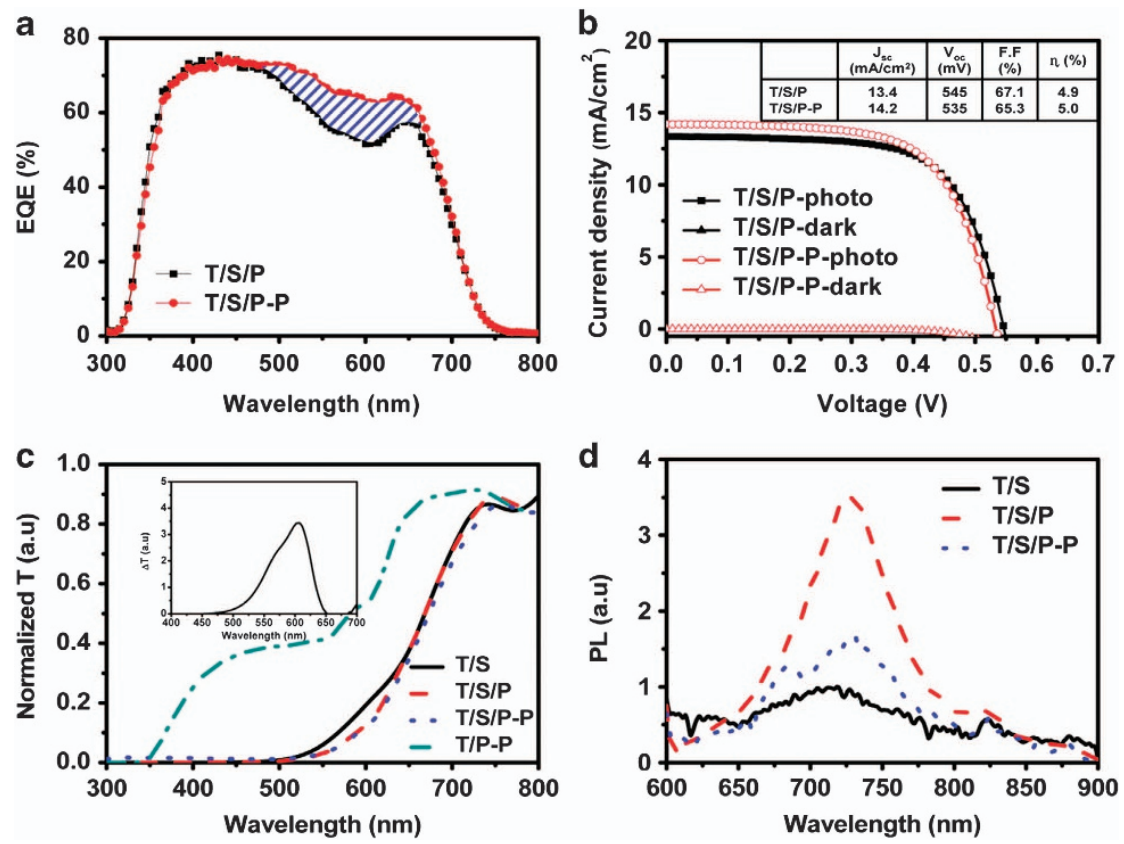

Figure 9 (a) EQE spectra: the region marked with blue lines is the EQE difference between the T/S/P-P and T/S/P samples. (b) J-V curves at $100 \mathrm{~mW} \cdot \mathrm{cm}^{-2}$ light illumination (photo) and no illumination (dark). (c) Transmission spectra: the inset shows the transmission difference between the T/S/ $\mathrm{P}-\mathrm{P}$ and T/S/P samples. (d) PL spectra. The following abbreviations appear in the figure: $T=\mathrm{mp}-\mathrm{TiO}_{2}, S=\mathrm{Sb}_{2} \mathrm{~S}_{3}, P=\mathrm{P} 3 \mathrm{HT}$ and $P-P=\mathrm{P} 3 \mathrm{HT} / \mathrm{PCBM}$ (adapted from Chang et al., ${ }^{15}$ copyright 2012, American Chemical Society).

devices, the challenges involve finding an effective synthetic method for the $\mathrm{Sb}_{2} \mathrm{Se}_{3}$ nanocrystals deposited on the mesoporous film and finding a suitable HTM to match the energy levels.

Haque and co-workers reported TAS results for $\mathrm{TiO}_{2} / \mathrm{Sb}_{2} \mathrm{Se}_{3} /$ spiroOMeTAD devices. ${ }^{99} \mathrm{Sb}_{2} \mathrm{Se}_{3}$ nanocrystals were deposited on the surface of $\mathrm{TiO}_{2}$ (or $\mathrm{ZrO}_{2}$ as a control experiment) with the SILAR method using $\mathrm{SbCl}_{3}$ dissolved in acetone and selenide dissolved in ethanol under a $\mathrm{N}_{2}$ atmosphere. The optical absorption of the $\mathrm{Sb}_{2} \mathrm{Se}_{3}$ nanocrystals increased and red-shifted with increasing SILAR cycles because of the increased surface coverage (QD loading) and size of the nanoparticles. Figure 11 shows the TA profiles and the energy level diagrams for the $\mathrm{Sb}_{2} \mathrm{Se}_{3}$ system with $\mathrm{TiO}_{2}$ and $\mathrm{ZrO}_{2}$ films; the yield of long-lived charge-separated states in the $\mathrm{TiO}_{2}$ films was triple that in the $\mathrm{ZrO}_{2}$ films because of the more rapid charge recombination of the latter. With increasing annealing temperature, the yield of charge separation was decreased, and the recombination lifetime also decreased because of the increased aggregation of the $\mathrm{Sb}_{2} \mathrm{Se}_{3}$ nanoparticles and the oxidation of the $\mathrm{Sb}_{2} \mathrm{Se}_{3}$ surface. A passivation layer of $\operatorname{In}_{x}(\mathrm{OH})_{y} \mathrm{~S}_{z}$ between $\mathrm{TiO}_{2}$ and $\mathrm{Sb}_{2} \mathrm{Se}_{3}$ can diminish the interfacial charge recombination and thus increase the decay coefficients of the transient signals by $\sim 10$ times. For the $\mathrm{TiO}_{2} / \mathrm{Sb}_{2} \mathrm{Se}_{3} /$ spiro-OMeTAD devices, the spiro-OMeTAD ${ }^{+}$charge yield was increased from 45 to $80 \%$, and the lifetime of the separated charges was $\sim 50 \mathrm{~ms}$ because of an effective match of the energy levels, a greater $\mathrm{Sb}_{2} \mathrm{Se}_{3}$ coverage on the $\mathrm{TiO}_{2}$ film and the decreased interfacial charge recombination. For the $\mathrm{ZrO}_{2} / \mathrm{Sb}_{2} \mathrm{Se}_{3}$ /spiro-OMeTAD devices, small transient signals were observed due to an electron transfer from $\mathrm{Sb}_{2} \mathrm{Se}_{3}$ to the spiro-OMeTAD. In this device, the transient signals in the $\mathrm{ZrO}_{2}$ films decayed much more rapidly than those in the $\mathrm{TiO}_{2}$ film. The rapid decays observed in the $\mathrm{ZrO}_{2}$ films are related to the recombination of the localized electrons inside the $\mathrm{Sb}_{2} \mathrm{Se}_{3}$ layer and the holes in the spiro-OMeTAD. The TAS results thus indicate that
$\mathrm{Sb}_{2} \mathrm{Se}_{3}$ might be an effective material for light harvesting in a highly efficient solid-state solar cell.

\section{PEROVSKITE-BASED MESOSCOPIC SOLAR CELLS}

Perovskite originally referred to a mineral containing $\mathrm{CaTiO}_{3}$, named after Russian mineralogist Lev Perovski, and the term was later extended to encompass a class of compounds with a crystal structure of the same type as $\mathrm{CaTiO}_{3}$. Figure 12 shows the unit cell of a threedimensional crystal structure for perovskite compounds with the general chemical formula $\mathrm{ABX}_{3}$. Instead of oxide perovskite species $(\mathrm{X}=\mathrm{O})$, halide perovskite compounds $(\mathrm{X}=\mathrm{Cl}, \mathrm{Br}$ or $\mathrm{I})$ were found to feature excellent light-harvesting and electron-conducting properties and are perfectly suitable for use as prospective photovoltaic materials. ${ }^{1-3}$

\section{Perovskite-sensitized solar cells with liquid electrolytes}

In 2009, Miyasaka and co-workers ${ }^{100}$ reported the first perovskitesensitized $\mathrm{TiO}_{2}$ solar cell using liquid electrolytes based on iodide and bromide. According to their approach, lead bromide perovskite $\left(\mathrm{CH}_{3} \mathrm{NH}_{3} \mathrm{PbBr}_{3}\right)$ was deposited on the $\mathrm{TiO}_{2}$ film with a spincoating procedure with the precursor solution containing $\mathrm{CH}_{3} \mathrm{NH}_{3} \mathrm{Br}$ and $\mathrm{PbBr}_{2}$. The coated $\mathrm{TiO}_{2}$ film showed nanocrystalline particles approximately $2-3 \mathrm{~nm}$ in size on the surface of the $\mathrm{TiO}_{2}$ nanoparticles. For these $\mathrm{TiO}_{2} / \mathrm{CH}_{3} \mathrm{NH}_{3} \mathrm{PbBr}_{3}$ solar cells, the IPCE action spectrum showed a maximum value of $65 \%$ at $\sim 400 \mathrm{~nm}$, but it fell to zero beyond $550 \mathrm{~nm}$. The corresponding device with $J_{\mathrm{SC}}=5.57 \mathrm{mAcm}^{-2}, V_{\mathrm{OC}}=0.96 \mathrm{~V}$ and $\mathrm{FF}=0.59$ gave a PCE of $3.1 \%$ under one-sun illumination. ${ }^{100}$ For these $\mathrm{TiO}_{2} /$ $\mathrm{CH}_{3} \mathrm{NH}_{3} \mathrm{PbI}_{3}$ solar cells, the IPCE spectrum showed effective optical absorption up to $800 \mathrm{~nm}$ with a maximum value of $45 \%$ at $\sim 500 \mathrm{~nm}$. As a result, the PCE $(3.8 \%)$ was larger for the iodide perovskite device than for the bromide perovskite device because $J_{\mathrm{SC}}\left(11.0 \mathrm{~mA} \mathrm{~cm}^{-2}\right)$ 

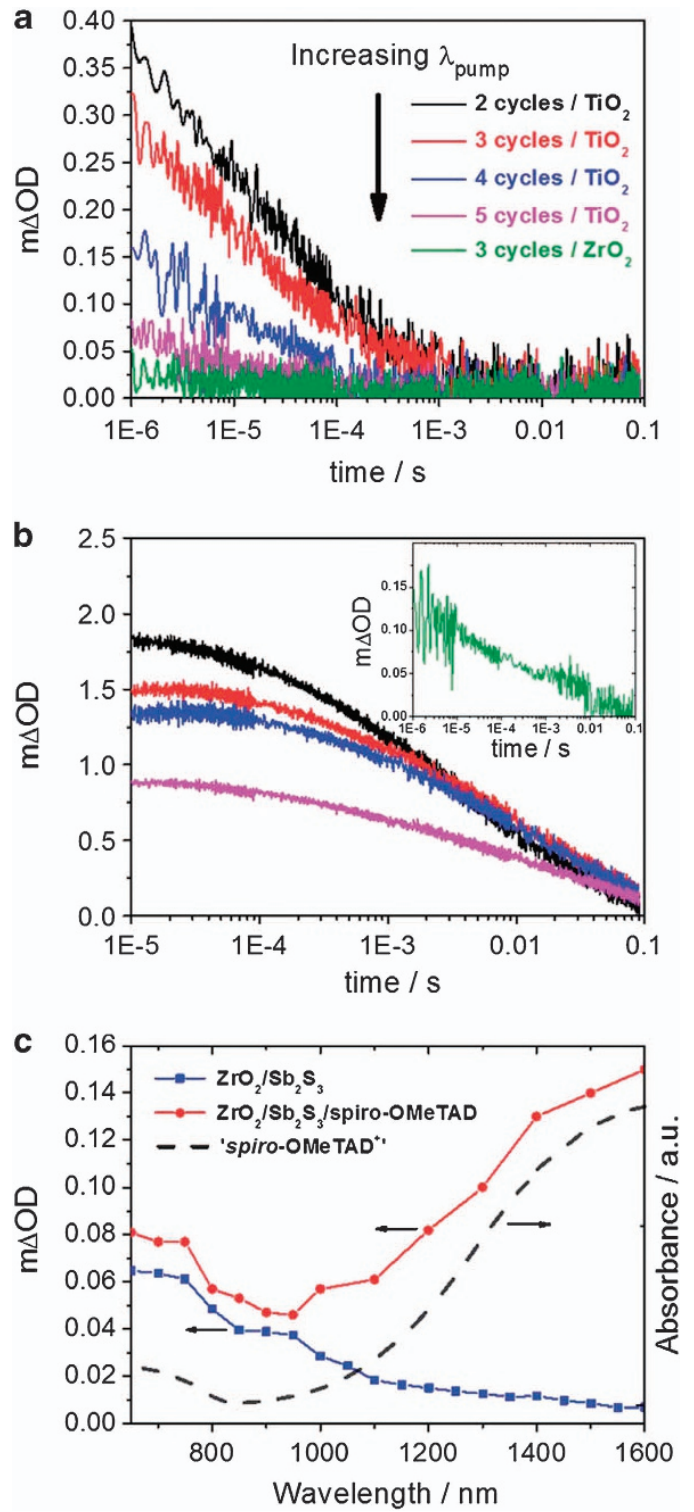

Figure 10 (a) Decay kinetics of the transient absorption of $\mathrm{Sb}_{2} \mathrm{~S}_{3}$-localized holes in metal-oxide/ $\mathrm{Sb}_{2} \mathrm{~S}_{3} /$ films probed at $800 \mathrm{~nm}$. (b) Transient decay kinetics of spiro-OMeTAD ${ }^{+}$absorption in $\mathrm{TiO}_{2} / \mathrm{Sb}_{2} \mathrm{~S}_{3}$ /spiro-OMeTAD (main figure) and $\mathrm{ZrO}_{2} / \mathrm{Sb}_{2} \mathrm{~S}_{3} /$ spiro-OMeTAD (inset) films probed at $1600 \mathrm{~nm}$. In both (a) and (b), $\lambda_{\text {pump }}$ is varied to probe increasingly red-absorbing nanocrystals while ensuring similar ground state absorbance (2 SILAR cycles (black trace) $-450 \mathrm{~nm}$ excitation, 3 cycles (red) $-510 \mathrm{~nm}, 4$ cycles (blue) $-570 \mathrm{~nm}, 5$ cycles (pink)-650 nm). Values of $\Delta \mathrm{OD}$ are scaled to the number of photons absorbed at $\lambda_{\text {pump. }}$ Laser excitation energy density $=26 \mu \mathrm{J} \mathrm{cm}^{-2}$ at $450 \mathrm{~nm}$. (c) Transient absorption spectra of $\mathrm{ZrO}_{2} /$ $\mathrm{Sb}_{2} \mathrm{~S}_{3}$ (blue trace) and $\mathrm{ZrO}_{2} / \mathrm{Sb}_{2} \mathrm{~S}_{3} /$ spiro-OMeTAD (red trace) recorded $1 \mu \mathrm{s}$ after photoexcitation at $510 \mathrm{~nm}$ (laser excitation energy density $=40 \mu \mathrm{J} \mathrm{cm}^{-2}$ ). Absorption spectrum of spiro-OMeTAD in chlorobenzene chemically oxidized with $\mathrm{N}(\mathrm{PhBr})_{3} \mathrm{SbCl}_{6}$ (black dashed trace) (adapted from OMahony et al., ${ }^{93}$ copyright 2012, Royal Society of Chemistry).

was much greater for the former than for the latter, even though the $V_{\mathrm{OC}}$ of the former device was only $0.61 \mathrm{~V}$.

Later in 2011, Park and co-workers ${ }^{101}$ reported on the improved efficiency of $\mathrm{TiO}_{2}$ solar cells sensitized with lead iodide perovskite $\left(\mathrm{CH}_{3} \mathrm{NH}_{3} \mathrm{PbI}_{3}\right)$ and an electrolyte based on iodide. In their approach,
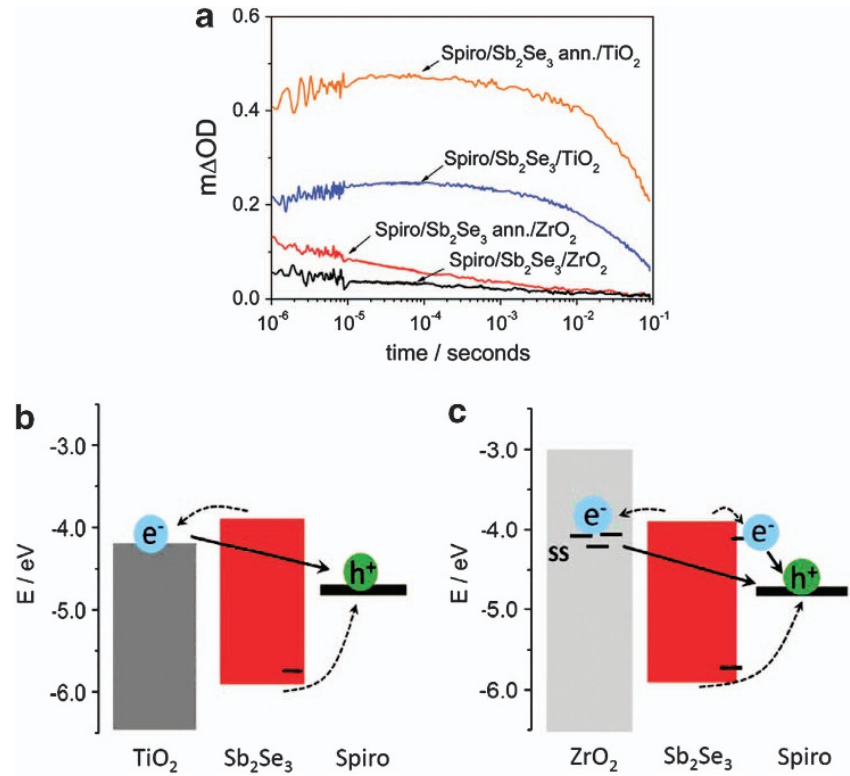

Figure 11 (a) Transient kinetics of spiro-OMeTAD/Sb $\mathrm{Se}_{3} / \mathrm{TiO}_{2}$ and spiroOMeTAD/Sb${ }_{2} \mathrm{Se}_{3} / \mathrm{ZrO}_{2}$ films recorded at $1600 \mathrm{~nm}$. (b, c) The energy diagrams of the systems include the recombination paths monitored with transient optical measurements (solid arrows) and previous processes (dashed arrows). All measurements were taken under $\mathrm{N}_{2}$, exciting all samples at $450 \mathrm{~nm}$ (fluency $6.9 \mu \mathrm{J} \mathrm{cm}^{-2}$ ). The energy level for spiroOMeTAD was reported elsewhere (adapted from Guijjaro et al., ${ }^{99}$ copyright 2012, American Chemical Society).

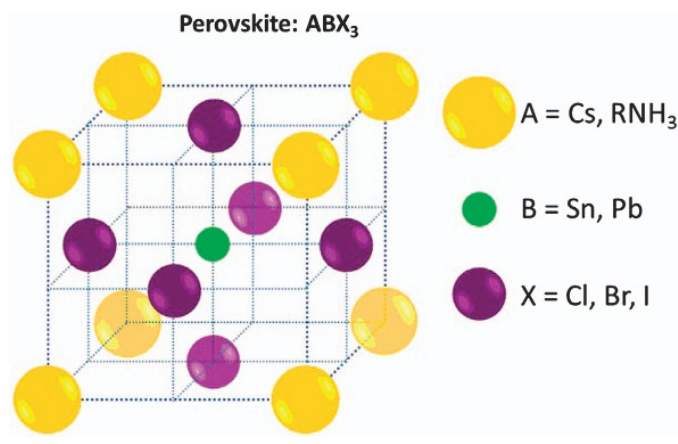

Figure 12 Schematic representation of the organometal-halide perovskite structures $\mathrm{ABX}_{3}$ with possible species $\mathrm{A}, \mathrm{B}$ and $\mathrm{X}$ as indicated.

$\mathrm{Pb}\left(\mathrm{NO}_{3}\right)_{2}$ was used for modification of the surface of a mesoporous $\mathrm{TiO}_{2}$ film before coating the perovskite QD, such that $\mathrm{Pb}\left(\mathrm{NO}_{3}\right)_{2}$ acted as a blocking layer in the solar cells. After the $\mathrm{TiO}_{2}$ surface modification, the device showed an improved PCE of $6.5 \%$ with $J_{\mathrm{SC}}=15.8 \mathrm{~mA} \mathrm{~cm}^{-2}, V_{\mathrm{OC}}=0.70 \mathrm{~V}$ and $\mathrm{FF}=0.58$; the improved $V_{\mathrm{OC}}$ was due to the retarded charge recombination effected by the surface treatment. The authors also mentioned the stability of the perovskite nanocrystals in the iodide electrolyte, whereby the perovskite QD gradually dissolved into the iodide electrolyte after being irradiated for $10 \mathrm{~min}$.

The organic part of the perovskite species is modifiable through a similar synthetic approach. For example, a $\mathrm{CH}_{3} \mathrm{CH}_{2} \mathrm{NH}_{3} \mathrm{PbI}_{3}$ sensitizer can be deposited on a mesoporous $\mathrm{TiO}_{2}$ film via spin coating with an equimolar mixture of $\mathrm{CH}_{3} \mathrm{CH}_{2} \mathrm{NH}_{3} \mathrm{I}$ and $\mathrm{PbI}_{2}$ in a $\gamma$-butyrolactone solution. ${ }^{102}$ The average diameter of the 
$\mathrm{CH}_{3} \mathrm{CH}_{2} \mathrm{NH}_{3} \mathrm{PbI}_{3}$ nanocrystals was approximately $1.8 \mathrm{~nm}$; the optical band gap of this species increased to $\sim 2.2 \mathrm{eV}$, as estimated from the diffuse reflectance spectra. For the $\mathrm{TiO}_{2} / \mathrm{CH}_{3} \mathrm{CH}_{2} \mathrm{NH}_{3} \mathrm{PbI}_{3}$ solar cells, the IPCE spectrum attained a maximum value of $\sim 60 \%$ at $\sim 600 \mathrm{~nm}$, giving a PCE of $2.4 \%$ in the iodide-based electrolyte. The poor performance of the device was due to the large optical band gap of the perovskite sensitizer of this type, which limited light harvesting in the visible region.

\section{Synthesis of lead-iodide perovskites on metal-oxide films}

Perovskite $\mathrm{CH}_{3} \mathrm{NH}_{3} \mathrm{PbI}_{3}$ nanocrystals were formed on mesoporous $\mathrm{TiO}_{2}$ films via spin coating with a solution containing $\mathrm{CH}_{3} \mathrm{NH}_{3} \mathrm{I}$ and $\mathrm{PbI}_{2}$ in an equimolar ratio. ${ }^{12,101}$ The concentrations of the spincoating solution were varied from 10 to $40 \%$ by mass in $\gamma$-butyrolactone. The nanocrystalline $\left(\mathrm{CH}_{3} \mathrm{NH}_{3}\right) \mathrm{PbI}_{3}$ layer formed on the surface of the $\mathrm{TiO}_{2}$ film after drying at temperatures from 40 to $160{ }^{\circ} \mathrm{C}$ for $30 \mathrm{~min}$, typically at $100{ }^{\circ} \mathrm{C}$ for $30 \mathrm{~min}$. With an increasing concentration of the coating solution, the color of the perovskite $\left(\mathrm{CH}_{3} \mathrm{NH}_{3}\right) \mathrm{PbI}_{3}$ on the $\mathrm{TiO}_{2}$ film varied from yellow $(10 \%$ by mass) to black ( $40 \%$ by mass). These perovskite nanocrystalline materials have an average diameter of approximately $2.5 \mathrm{~nm}$, showing QD behavior on the surface of the $\mathrm{TiO}_{2}$ nanoparticles, according to the TEM images shown in Figure 13. ${ }^{101}$

Instead of the mesoporous $\mathrm{TiO}_{2}$ film, an insulating $\mathrm{Al}_{2} \mathrm{O}_{3}$ layer served as a scaffold for coating the perovskite halide $\left(\mathrm{CH}_{3} \mathrm{NH}_{3} \mathrm{PbI}_{2} \mathrm{Cl}\right)$ as a light harvester on the surface of the $\mathrm{Al}_{2} \mathrm{O}_{3}$ film. The perovskite nanocrystalline film was prepared from a precursor solution containing $\mathrm{CH}_{3} \mathrm{NH}_{3} \mathrm{I}$ and $\mathrm{PbCl}_{2}$ in a molar ratio of 3:1 in anhydrous $\mathrm{N}, \mathrm{N}$-dimethylformamide. ${ }^{11}$ After spin-coating and drying, the halide perovskite absorber on the $\mathrm{Al}_{2} \mathrm{O}_{3}$ film had an I:Cl ratio of approximately 2:1, according to the energy-dispersive X-ray analysis.
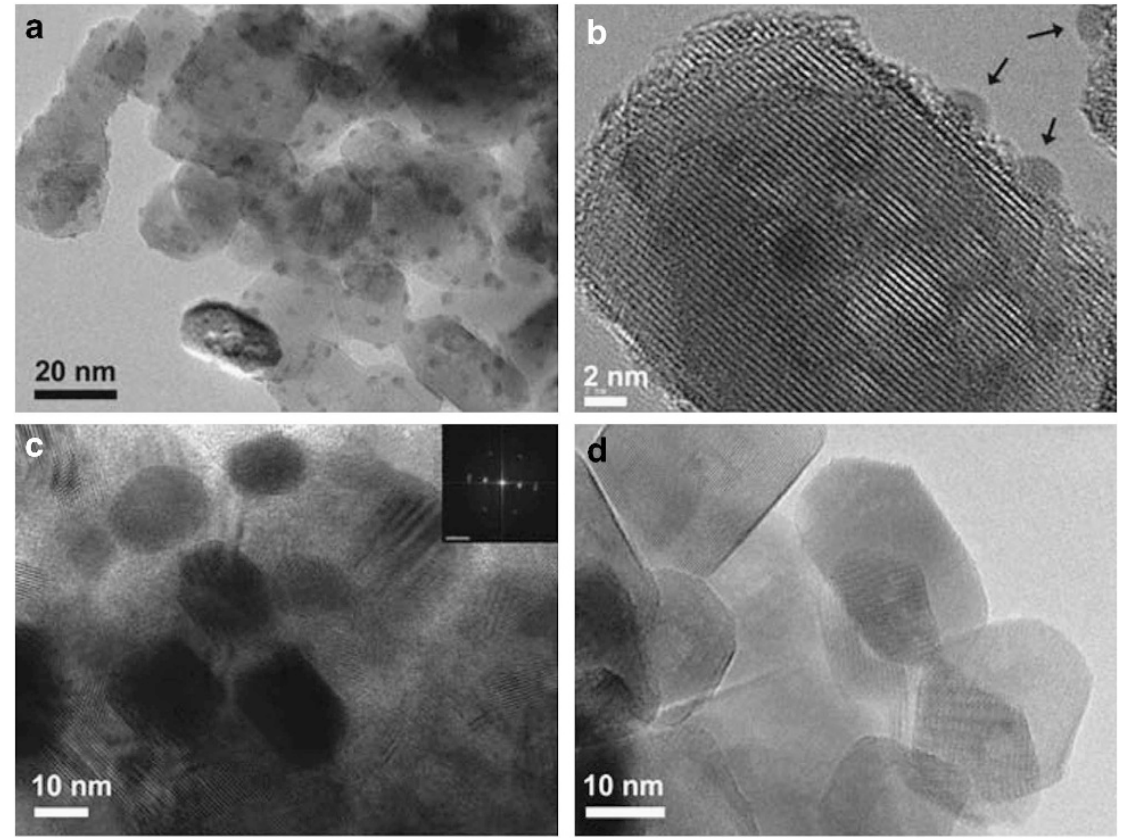

Figure 13 TEM micrographs of (a) a wide view of $\left(\mathrm{CH}_{3} \mathrm{NH}_{3}\right) \mathrm{Pbl}_{3}$ deposited on $\mathrm{TiO}_{2}$, (b) a magnified image of $\left(\mathrm{CH}_{3} \mathrm{NH}_{3}\right) \mathrm{Pbl}_{3}$ deposited on $\mathrm{TiO}_{2}$, (c) pure $\left(\mathrm{CH}_{3} \mathrm{NH}_{3}\right) \mathrm{Pbl}_{3}$ and (d) bare $\mathrm{TiO}_{2}$. Arrows in (b) indicate quantum dot perovskite $\left(\mathrm{CH}_{3} \mathrm{NH}_{3}\right) \mathrm{Pbl}$, with a hemispherical shape. Inset in (c) shows a selectedarea electron-diffraction pattern of pure $\left(\mathrm{CH}_{3} \mathrm{NH}_{3}\right) \mathrm{Pbl}$. For the (a) and (b) TEM images, 30.18 and $40.26 \%$ (by mass) perovskite precursor solutions were used, respectively (adapted from Im et al., ${ }^{101}$ copyright 2011, Royal Society of Chemistry). 


\section{Photovoltaic characteristics of perovskite solar cells}

Perovskite $\mathrm{CH}_{3} \mathrm{NH}_{3} \mathrm{PbI}_{3}$ nanocrystals have large coefficients of optical absorption in the visible region, ranging from $10^{4}$ to $10^{5} \mathrm{~cm}^{-1} .12$ These nanocrystals also have excellent matching of energy levels with those of $\mathrm{TiO}_{2}$. Interfacial bonding of perovskites with $\mathrm{TiO}_{2}$ and spiroOMeTAD was effective in ensuring uniform penetration and complete filling of the pores. Figure 15 shows the photovoltaic performance of the corresponding device; the IPCE values attained a maximum higher than $60 \%$ at $450 \mathrm{~nm}$ and were maintained greater than $50 \%$ up to $750 \mathrm{~nm}$. The IPCE characteristics indicate that the $\mathrm{CH}_{3} \mathrm{NH}_{3} \mathrm{PbI}_{3}$ nanocrystals deposited on the mesoporous $\mathrm{TiO}_{2}$ film feature excellent light-harvesting properties, bestowing an excellent quantum efficiency to the device in the visible region. The perovskite device of $0.6-\mu \mathrm{m}$ film thickness showed a high photocurrent density $\left(J_{\mathrm{SC}}=17.6\right.$ $\left.\mathrm{mAcm}^{-2}\right)$ and $V_{\mathrm{OC}}(=0.88 \mathrm{~V})$, a satisfactory $\mathrm{FF}(=0.62)$ and excellent overall device performance $(\eta=9.7 \%)$ under one-sun irradiation. ${ }^{12}$ With increased thickness of the $\mathrm{TiO}_{2}$ film, both $V_{\mathrm{OC}}$ and $\mathrm{FF}$ of the device decreased because of the increased dark current and resistance to electron transport. The results obtained from the TAS measurements indicate that the holes were completely transferred from the perovskite sensitizer to the spiro-OMeTAD HTM after charge separation in the sensitizer; the normalized photocurrent density was linearly proportional to the light intensity (Figure 15), without charge loss. ${ }^{12}$

Mixed-halide perovskite $\left(\mathrm{CH}_{3} \mathrm{NH}_{3} \mathrm{PbI}_{2} \mathrm{Cl}\right)$ nanocrystals have an optical absorption onset $(\lambda \sim 800 \mathrm{~nm})$ similar to that of the iodide perovskite $\left(\mathrm{CH}_{3} \mathrm{NH}_{3} \mathrm{PbI}_{3}\right)$ mentioned previously. Figure 16 presents a comparison of the photovoltaic performance of the $\mathrm{CH}_{3} \mathrm{NH}_{3} \mathrm{PbI}_{3} \mathrm{SCs}$ using either the $\mathrm{TiO}_{2}$ or the $\mathrm{Al}_{2} \mathrm{O}_{3}$ film as the metal-oxide layer. ${ }^{11}$ For the $\mathrm{Al}_{2} \mathrm{O}_{3}$-based device, the IPCE curve attains a maximum value greater than $80 \%$ at $400 \mathrm{~nm}$, and the values are maintained at greater than $60 \%$ up to $700 \mathrm{~nm}$; for the $\mathrm{TiO}_{2}$-based device, the IPCE values are slightly smaller than those of the $\mathrm{Al}_{2} \mathrm{O}_{3}$-based device, with similar $J_{\mathrm{SC}}$ for both devices. ${ }^{11}$ The $V_{\mathrm{OC}}$ of the $\mathrm{Al}_{2} \mathrm{O}_{3}$ device was, however, much greater than that of the $\mathrm{TiO}_{2}$ device because the loss of injection potential was much less for the former than for the latter. As a result, $V_{\text {OC }}$ significantly increased $(\sim 200 \mathrm{mV})$ for the devices from the $\mathrm{TiO}_{2}$ film to the insulating $\mathrm{Al}_{2} \mathrm{O}_{3}$ film, and the best device efficiency of $10.9 \%$ was found for the $\mathrm{Al}_{2} \mathrm{O}_{3}$ device under one-sun conditions. ${ }^{11}$

In 2013, Snaith and co-workers ${ }^{2}$ reported highly efficient perovskite $\mathrm{CH}_{3} \mathrm{NH}_{3} \mathrm{~Pb}(\mathrm{I}, \mathrm{Cl})_{3}$ solar cells, with the efficiency of the best device approaching $12.3 \%$ based on a mesoporous $\mathrm{Al}_{2} \mathrm{O}_{3}$ film that was a
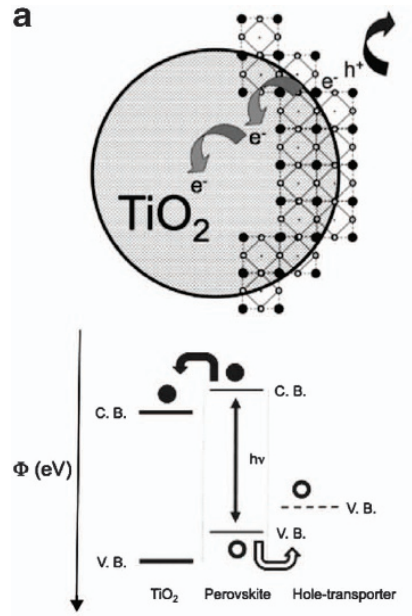
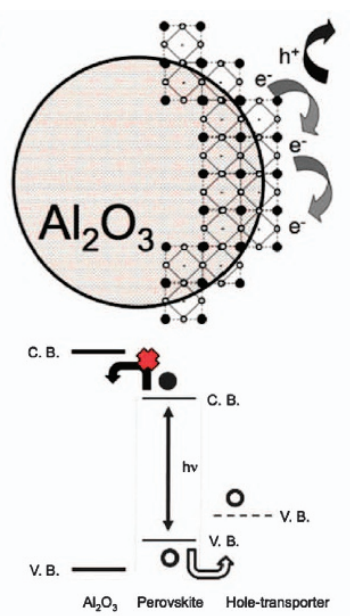
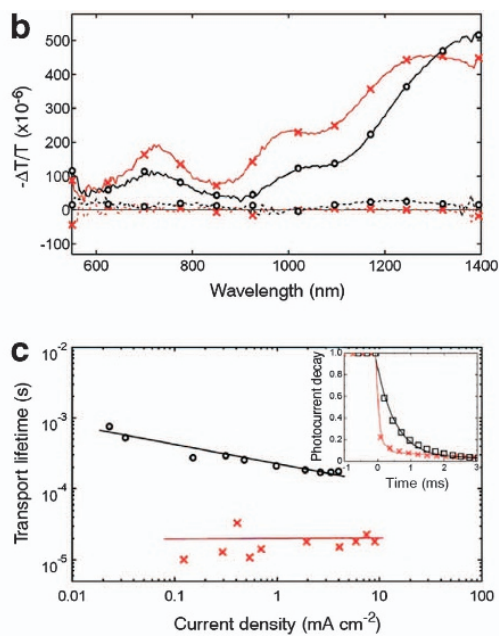

Figure 14 (a) Illustration of charge transfer and transport in a perovskite-sensitized $\mathrm{TiO}_{2}$ solar cell (left) and a non-injecting $\mathrm{Al}_{2} \mathrm{O}_{3}$-based perovskite solar cell (right). (b) Photo-induced absorbance (PIA) spectra of mesoporous $\mathrm{TiO}_{2}$ (black open circles) and $\mathrm{Al}_{2} \mathrm{O}_{3}$ (red crosses) films coated with perovskite with (solid lines) and without (dashed lines) spiro-OMeTAD hole transporter. $\lambda_{\mathrm{ex}}=496.5 \mathrm{~nm}$, repetition rate $23 \mathrm{~Hz}$. (c) Charge transport lifetime determined with a small-perturbation transient photocurrent decay of perovskite-sensitized $\mathrm{TiO}_{2}$ (circles with a black line) and $\mathrm{Al}_{2} \mathrm{O}_{3}$ cells (red crosses with a line). Inset shows normalized photocurrent transients for $\mathrm{Al}_{2} \mathrm{O}_{3}$ (red trace with crosses every seventh point) and $\mathrm{TiO}_{2}$ (black trace with circles every seventh point) cells, set to generate $5 \mathrm{~mA} \cdot \mathrm{cm}^{-2}$ photocurrent from a background light bias (adapted from Lee et al., ${ }^{11}$ copyright 2012, American Association for the Advancement of Science).
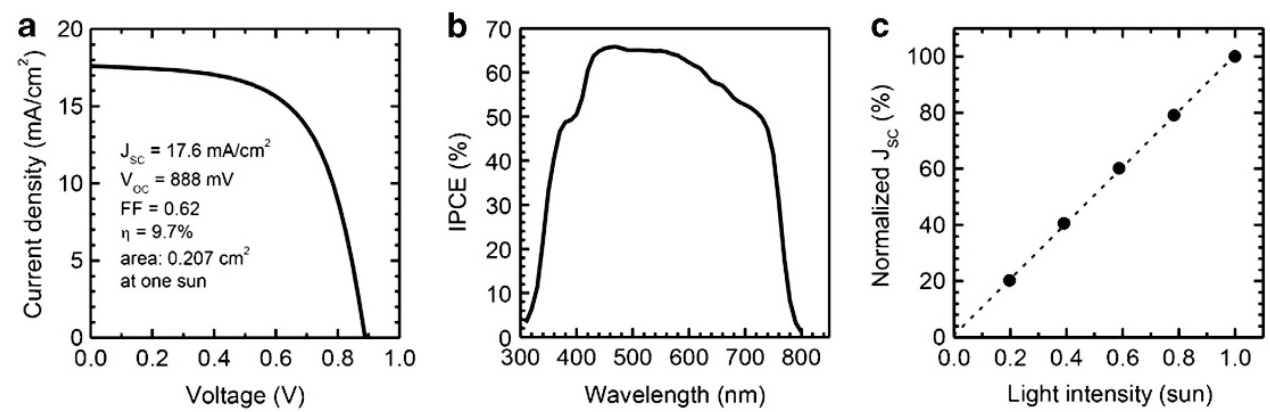

Figure 15 Photovoltaic characteristics of a $\left(\mathrm{CH}_{3} \mathrm{NH}_{3}\right) \mathrm{Pbl}_{3}$ perovskite-sensitized solar cell. (a) Photocurrent density as a function of forward bias voltage. (b) IPCE as a function of incident wavelength. (c) Short-circuit photocurrent density as a function of light intensity (adapted from Kim et al., ${ }^{12}$ copyright 2012, Scientific Reports). 

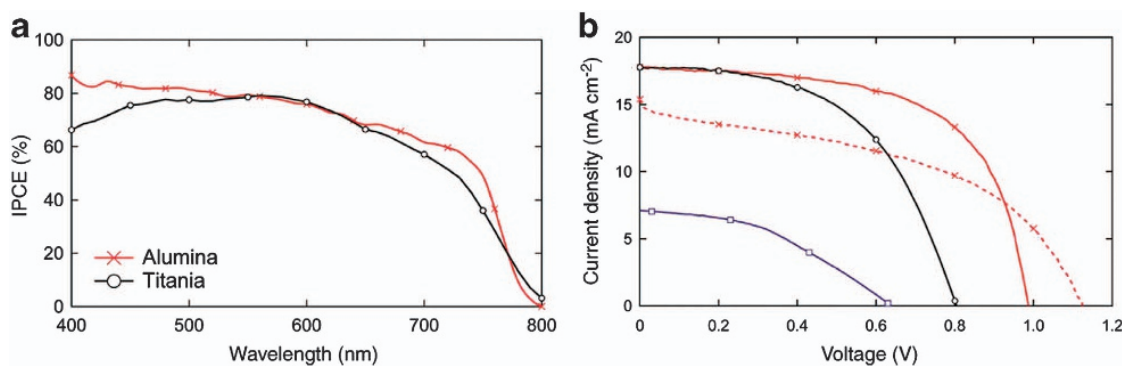

Figure 16 (a) IPCE action spectrum of an $\mathrm{Al}_{2} \mathrm{O}_{3}$-based and perovskite-sensitized $\mathrm{TiO}_{2}$ solar cell, with a device structure of $\mathrm{FTO} / \mathrm{compact}^{\mathrm{TiO}} 2 / \mathrm{mesoporous}$ $\mathrm{Al}_{2} \mathrm{O}_{3}$ (red trace with crosses) or mesoporous $\mathrm{TiO}_{2}$ (black trace with circles)/ $\mathrm{CH}_{3} \mathrm{NH}_{3} \mathrm{Pbl}_{2} \mathrm{Cl} / \mathrm{Spiro}-\mathrm{OMeTAD} / \mathrm{Ag}$. (b) Current-voltage characteristics under illumination (simulated $\mathrm{AM} 1.5 \mathrm{G} 100 \mathrm{~mW} \mathrm{~cm}^{-2}$ ) for $\mathrm{Al}_{2} \mathrm{O}_{3}$-based cells, with one cell exhibiting great efficiency (red solid trace with crosses) and one exhibiting greater than $V_{\mathrm{OC}} 1.1 \mathrm{~V}$ (red dashed line with crosses); a perovskite $\mathrm{TiO}_{2}$-sensitized solar cell (black trace with circles); and a planar-junction diode with a structure $\mathrm{FTO} / \mathrm{compact} \mathrm{TiO}_{2} / \mathrm{CH}_{3} \mathrm{NH}_{3} \mathrm{Pbl}{ }_{2} \mathrm{Cl} / \mathrm{Sp}$ iro-OMeTAD/Ag (purple trace with squares) (adapted from Lee et al., ${ }^{11}$ copyright 2012, American Association for the Advancement of Science).

$\sim 0.4 \mu \mathrm{m}$ thick. For the $\mathrm{Al}_{2} \mathrm{O}_{3}$ films with a thickness less than $0.4 \mu \mathrm{m}$, the perovskite solar cell had an efficiency of $\sim 9.1 \%$ with a capping layer of thickness of $0.3-0.4 \mu \mathrm{m}$. For the $\mathrm{Al}_{2} \mathrm{O}_{3}$ films with a thickness greater than $0.4 \mu \mathrm{m}$, the perovskite solar cells had, in contrast, an efficiency near $12 \%$ without a perovskite capping layer. Seok and coworkers reported on perovskite $\mathrm{CH}_{3} \mathrm{NH}_{3} \mathrm{~Pb}(\mathrm{I}, \mathrm{Br})_{3}$ solar cells with a maximum efficiency of $12.3 \% .^{3}$ In contrast with the approach of Snaith, using the $\mathrm{Al}_{2} \mathrm{O}_{3}$ film as a scaffold for perovskites, the best device performance of Seok's method was achieved using $\mathrm{TiO}_{2}$ films of thickness $\sim 0.6 \mu \mathrm{m}$. For the mesoporous $\mathrm{TiO}_{2}$-based devices, the efficiency was optimized by using an alloy comprising both $\mathrm{CH}_{3} \mathrm{NH}_{3} \mathrm{PbI}_{3}$ and $\mathrm{CH}_{3} \mathrm{NH}_{3} \mathrm{PbBr}_{3}$ crystals, resulting in increased device efficiency and superior device stability. The mixing ratios of the solutions containing perovskites $\mathrm{CH}_{3} \mathrm{NH}_{3} \mathrm{~Pb}\left(\mathrm{I}_{1-x} \mathrm{Br}_{x}\right)_{3}$ were reported for $x$ varying in the range of $0.06-0.20$. Figure 17 presents the stability data of the devices, indicating that the devices containing less $\operatorname{Br}(x=0.06$ or zero) had a higher efficiency than the others in the initial stage of the test, whereas those containing more $\mathrm{Br}(x=0.20$ or 0.29 ) exhibited superior durability under ambient conditions because of their compact nanocrystalline structure.

Seok and co-workers also fabricated perovskite $\mathrm{CH}_{3} \mathrm{NH}_{3} \mathrm{PbI}_{3} /$ poly-triarylamine (PTAA) solar cells with an efficiency of $12 \% .{ }^{103}$ The device using PTAA as an HTM layer showed much better performance than those using other polymeric hole conductors such as P3HT $(\eta \sim 6.7 \%)$, PCPDTBT $(\eta \sim 5.3 \%)$ and PCDTBT $(\eta \sim 4.2 \%)$. Park and co-workers ${ }^{104}$ demonstrated perovskite $\mathrm{CH}_{3} \mathrm{NH}_{3} \mathrm{PbI}_{3}$ solar cells based on rutile $\mathrm{TiO}_{2}$ nanorods with an efficiency of $9.4 \%$. Park's results indicate that the photovoltaic performance was strongly dependent on the length of the $\mathrm{TiO}_{2}$ nanorods because of the efficiency of charge generation rather than because of the kinetics of charge recombination. Hagfeldt and coworkers ${ }^{105}$ reported perovskite $\mathrm{CH}_{3} \mathrm{NH}_{3} \mathrm{PbI}_{3}$ /spiro-OMeTAD solar cells with an efficiency of $8.5 \%$. The spiro-OMeTAD device showed a much improved performance compared with devices using P3HT $(\eta \sim 4.5 \%)$ and 4-(diethylamino)-benzaldehyde diphenylhydrazone (DEH) $(\eta \sim 1.6 \%)$ because of the greater electron lifetime of the former. Other perovskite-based HMSCs have been studied, with various $\mathrm{TiO}_{2}$ nanostructures and HTMs. ${ }^{106-109}$ Hagfeldt and coworkers ${ }^{110}$ reported $\mathrm{ZrO}_{2} / \mathrm{CH}_{3} \mathrm{NH}_{3} \mathrm{PbI}_{3}$ /spiro-OMeTAD solar cells with an efficiency of $10.8 \%$. Perovskite $\mathrm{CH}_{3} \mathrm{NH}_{3} \mathrm{PbI}_{3} /$ fullerene heterojunction hybrid solar cells have also been fabricated. ${ }^{111}$

Chung et al. ${ }^{112}$ reported the use of perovskite $\mathrm{CsSnI}_{3}$ as an HTM in solid-state DSSCs. Perovskite $\mathrm{CsSnI}_{3}$ is a direct band gap p-type

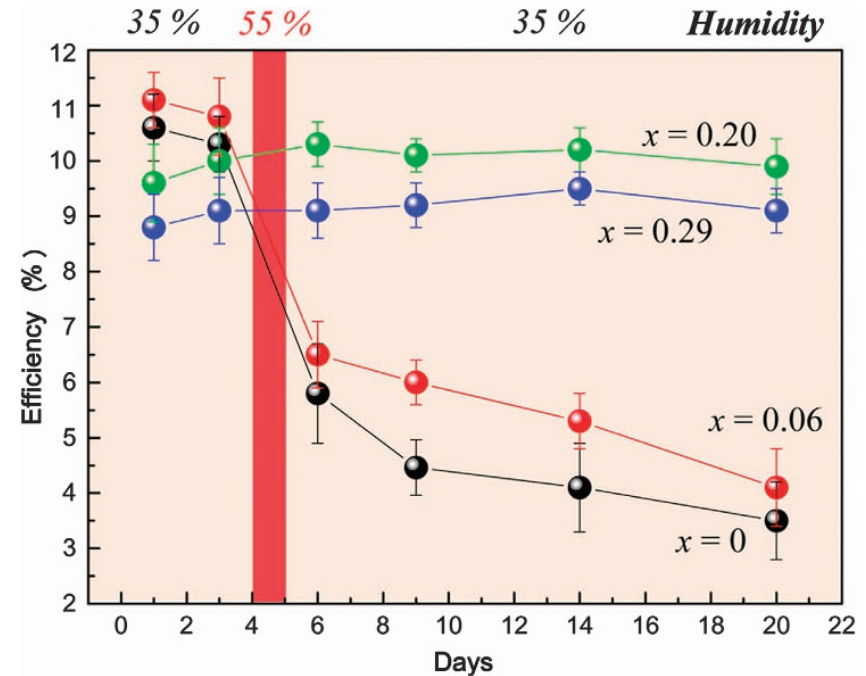

Figure 17 Variation of the power conversion efficiency of heterojunction solar cells based on $\mathrm{CH}_{3} \mathrm{NH}_{3} \mathrm{~Pb}\left(\mathrm{I}_{1-x} \mathrm{Br}_{x}\right)_{3}(x=0,0.06,0.20,0.29)$ with time, stored in air at around $23^{\circ} \mathrm{C}$ without encapsulation. The humidity was maintained at 35\%; the cells were exposed to $55 \%$ humidity on the fourth day to investigate the variation in performance under high humidity (adapted from Noh et al. ${ }^{3}$ copyright 2013, American Chemical Society).

semiconductor with an optical absorption onset at $1.3 \mathrm{eV}$ (Figure $1 \mathrm{~b}$ ), and it has a large hole mobility $\left(\mu_{\mathrm{h}}=585 \mathrm{~cm}^{2} \mathrm{~V}^{-1} \mathrm{~s}^{-1}\right)$ near $23^{\circ} \mathrm{C}$; the latter value is 100-1000 times that of a polymer-type HTM. As a result, the device consisting of $\mathrm{CsSnI}_{2.95} \mathrm{~F}_{0.05} / \mathrm{N} 719$ dye $/ \mathrm{TiO}_{2}$ attained a PCE of $8.5 \%$ with an enhanced IPCE in the red visible region. ${ }^{112}$ Chen et al. ${ }^{113}$ reported Schottky solar cells based on perovskite $\mathrm{CsSnI}_{3}$ thin films; these films were prepared by coating multiple layers of $\mathrm{SnCl}_{2}$ and $\mathrm{CsI}$ on a glass substrate followed by annealing at $175^{\circ} \mathrm{C}$ on a hotplate for $1 \mathrm{~min}$ under ambient conditions. The $\mathrm{CsSnI}_{3}$ film was formed during annealing from the $\mathrm{SnCl}_{2} / \mathrm{CsI}$ stack. The $\mathrm{JV}$ characteristic curve showed a small PCE $(0.88 \%)$ for an SC of this type. The perovskite mesoscopic solar cell without an HTM layer was reported to possess a PCE of 5.5\%. ${ }^{114}$

\section{Challenges in perovskite-based solar cells}

The synthesis of perovskite $\mathrm{CH}_{3} \mathrm{NH}_{3} \mathrm{PbI}_{3}$ nanocrystals is sensitive to ambient humidity. According to results reported elsewhere, ${ }^{101}$ the 
perovskites gradually dissolved into a liquid-type electrolyte after irradiation for $10 \mathrm{~min}$. As a result, anhydrous starting materials should be used in a dry box during synthesis. Another issue is the thickness and porosity of the HTM layer (such as spiro-OMeTAD) coated on the surface of the perovskite. For example, the contact resistance and series resistance at the interface of the $\mathrm{CH}_{3} \mathrm{NH}_{3} \mathrm{PbI}_{3} /$ spiro-OMeTAD/cathode must be decreased by optimizing the thickness of the spiro-OMeTAD layer. A thinner spiro-OMeTAD layer is required to decrease the series resistance and hole-transport

Table 1 Summary of the device performances for liquid-type QDSCs and perovskite solar cells

\begin{tabular}{|c|c|c|c|c|}
\hline Anode & Active layer & Electrolyte/CE & PCE (\%) & References \\
\hline $\mathrm{TiO}_{2}$ & $\mathrm{CulnS}_{2} / \mathrm{CdS}$ & Polysulfide/PbS & 4.7 & 71 \\
\hline $\mathrm{TiO}_{2}$ & CdSe & Polysulfide/Pt & 2.7 & 26 \\
\hline $\mathrm{TiO}_{2}$ & CdSe & Polysulfide/PbS & 3.3 & 30 \\
\hline $\mathrm{TiO}_{2}$ & $\mathrm{CdS} / \mathrm{CdSe}$ & Polysulfide/PbS & 3.9 & 72 \\
\hline $\mathrm{TiO}_{2}$ & $\mathrm{CdS} / \mathrm{CdSe}$ & QS polysulfide ${ }^{\mathrm{a}} / \mathrm{Cu}_{2} \mathrm{~S}$ & 4.0 & 42 \\
\hline $\mathrm{TiO}_{2}$ & $\mathrm{CdS} / \mathrm{CdSe}$ & Polysulfide/Au & 4.2 & 39 \\
\hline $\mathrm{TiO}_{2}$ & $\mathrm{CdS} / \mathrm{CdSe}$ & Polysulfide/ $\mathrm{Cu}_{2} \mathrm{~S}$ & 5.4 & 44 \\
\hline $\mathrm{TiO}_{2}$ & CdSes & Polysulfide/ $\mathrm{Cu}_{2} \mathrm{~S}$ & 3.2 & 45 \\
\hline $\mathrm{TiO}_{2}$ & $\mathrm{CdTe} / \mathrm{CdSe}$ & Polysulfide/PbS & 2.4 & 41 \\
\hline $\mathrm{TiO}_{2}$ & $\mathrm{PbS}$ & Polysulfide/ $\mathrm{Cu}_{2} \mathrm{~S}$ & 2.1 & 80 \\
\hline $\mathrm{TiO}_{2}$ & $\mathrm{PbS} / \mathrm{CdS}$ & Polysulfide/ $\mathrm{Cu}_{2} \mathrm{~S}$ & 3.8 & 68 \\
\hline $\mathrm{TiO}_{2}$ & $\mathrm{PbS}: \mathrm{Hg}$ & Polysulfide/ $\mathrm{Cu}_{2} \mathrm{~S}$ & 5.6 & 18 \\
\hline $\mathrm{TiO}_{2}$ & $\mathrm{PbS}$ & Polysulfide/Au/CuS & 5.7 & 73 \\
\hline $\mathrm{TiO}_{2}$ & PbSeS & Polysulfide/ $\mathrm{Cu}_{2} \mathrm{~S}$ & 1.5 & 80 \\
\hline $\mathrm{TiO}_{2}$ & $\mathrm{Sb}_{2} \mathrm{~S}_{3}$ & Cobalt-phen/Pt & 3.3 & 115 \\
\hline $\mathrm{TiO}_{2}$ & $\mathrm{CH}_{3} \mathrm{CH}_{2} \mathrm{NH}_{3} \mathrm{Pbl}_{3}$ & lodide/Pt & 2.4 & 102 \\
\hline $\mathrm{TiO}_{2}$ & $\mathrm{CH}_{3} \mathrm{NH}_{3} \mathrm{PbBr}_{3}$ & Bromide/Pt & 3.1 & 100 \\
\hline $\mathrm{TiO}_{2}$ & $\mathrm{CH}_{3} \mathrm{NH}_{3} \mathrm{Pbl}_{3}$ & lodide/Pt & 3.8 & 100 \\
\hline $\mathrm{TiO}_{2}$ & $\mathrm{CH}_{3} \mathrm{NH}_{3} \mathrm{Pbl}_{3}$ & lodide/Pt & 6.5 & 101 \\
\hline
\end{tabular}

Abbreviations: $\mathrm{CE}$, counter electrode; $\mathrm{QD}$, quantum dot; QS polysulfide, quasi-solid-state polysulfide; PCE, power conversion efficiency. ${ }^{a} \mathrm{QS}$ poly sulfide represents quasi-solid-state poly sulfide.

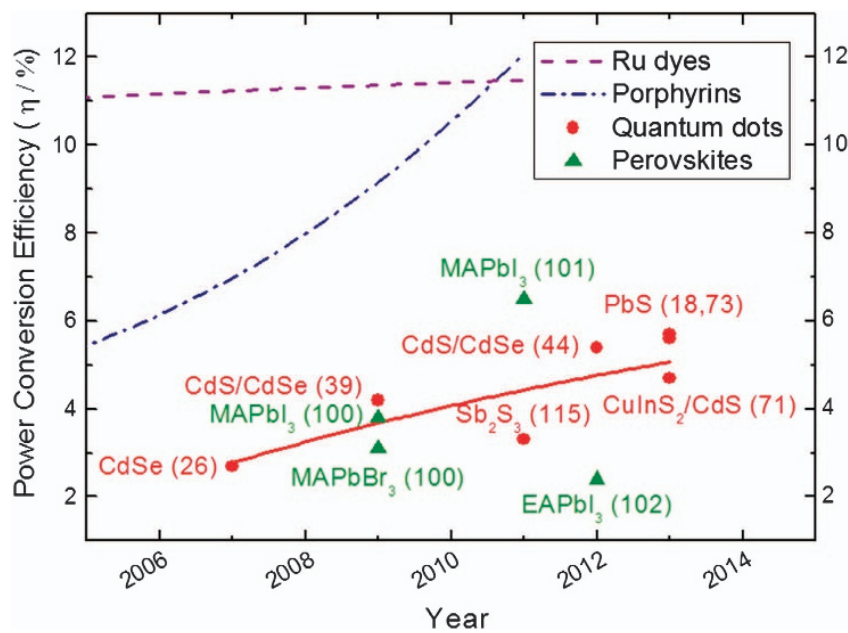

Figure 18 Charts of the efficiency progress of liquid-type QDSCs and perovskite-based SCs developed during the period 2007-2013. The solid curve represents the average progress trend with the corresponding references cited in parentheses. The dashed and dashed-dotted curves represent those of DSSCs with sensitizers of ruthenium complexes and porphyrin dyes, respectively. The symbols $\mathrm{MA}$ and $\mathrm{EA}$ represent perovskites with organic components of $\mathrm{CH}_{3} \mathrm{NH}_{3}$ and $\mathrm{CH}_{3} \mathrm{CH}_{2} \mathrm{NH}_{3}$, respectively. resistance through the spiro-OMeTAD to the cathode. As the conductivity of a typical halide perovskite is on the order of $10^{-3} \mathrm{~S} \mathrm{~cm}^{-1}$, the spiro-OMeTAD layer should be thick enough to prevent an electrical short circuit between the perovskite layer and the counter electrode. Greater FF and PCE of the devices can be achieved by employing new types of HTMs with greater mobility and by introducing a thin capping layer on the perovskite sensitizer. Nevertheless, the best-performing perovskite solar cell was reported in 2013 with a structure of $\mathrm{TiO}_{2}$ /perovskite/spiro$\mathrm{OMeTAD} / \mathrm{Au}$, which exhibited a remarkable PCE of $15.0 \%$ $\left(J_{\mathrm{SC}}=20.0 \mathrm{~mA} \mathrm{~cm}^{-2}, \quad V_{\mathrm{OC}}=0.993 \mathrm{~V}, \quad \mathrm{FF}=0.73\right) \quad$ under $\quad$ an illumination of $96.4 \mathrm{~mW} \mathrm{~cm}^{-2}{ }^{1}$ It is worth noting that when the device was encapsulated under argon, it could maintain greater than $80 \%$ of its initial PCE after $500 \mathrm{h.}^{1}$

\section{CONCLUSIONS}

Highly efficient dye-sensitized nanocrystalline $\mathrm{TiO}_{2}$ solar cells have been developed since $1991^{8}$; the most promising devices are based on

Table 2 Summary of the device performances for solid-state QDSCs and perovskite solar cells

\begin{tabular}{|c|c|c|c|c|}
\hline Anode & Active layer & HTM/CE & PCE (\%) & References \\
\hline $\mathrm{TiO}_{2}$ & $\mathrm{CdS}$ & Spiro-OMeTAD/Ag & 0.2 & 22 \\
\hline $\mathrm{TiO}_{2}$ & $\mathrm{CdS}$ & Spiro-OMeTAD/Au & 0.8 & 21 \\
\hline $\mathrm{TiO}_{2}$ & CdS & P3HT/Ag & 0.8 & 25 \\
\hline $\mathrm{TiO}_{2}$ & $\mathrm{CdS}$ & $\mathrm{P} 3 \mathrm{HT} / \mathrm{Au}$ & $1.4,2.1$ & 23,24 \\
\hline $\mathrm{TiO}_{2}$ & $\mathrm{CdSe}$ & QT12,pTPA/FTO & 0.3 & 31 \\
\hline $\mathrm{TiO}_{2}$ & $\mathrm{CdSe}$ & P3HT/Au & 1.6 & 28 \\
\hline $\mathrm{TiO}_{2}$ & $\mathrm{CdS} / \mathrm{CdSe}$ & Spiro-OMeTAD/Au & 0.8 & 46 \\
\hline $\mathrm{TiO}_{2}$ & CdTe & PCBM,P3HT/Pt,C60 & 3.4 & 35 \\
\hline $\mathrm{TiO}_{2}$ & CdTe & $\mathrm{PNV}, \mathrm{MoO}_{\mathrm{x}} / \mathrm{Au}$ & 3.6 & 34 \\
\hline $\mathrm{TiO}_{2}$ & $\mathrm{PbS}$ & Spiro-OMeTAD/Au & 1.4 & 21 \\
\hline $\mathrm{TiO}_{2}$ & $\mathrm{PbS}$ & P3HT/Au & $3.3,2.9$ & 57,58 \\
\hline $\mathrm{TiO}_{2} \mathrm{NS}$ & $\mathrm{PbS}$ & $\mathrm{Au}$ & 4.7 & 62 \\
\hline $\mathrm{TiO}_{2} \mathrm{NP}$ & $\mathrm{PbS}$ & $\mathrm{MoO}_{\mathrm{x}} / \mathrm{Au}$ & 5.6 & 56 \\
\hline $\mathrm{TiO}_{2}$ & $\mathrm{PbS}$ & $\mathrm{Au}$ & $5.5,6.0$ & 52,53 \\
\hline $\mathrm{TiO}_{2} / \mathrm{ZnO}$ & $\mathrm{PbS}$ & $\mathrm{MoO}_{\mathrm{x}} / \mathrm{Au}$ & 7.4 & 13 \\
\hline $\mathrm{TiO}_{2} \mathrm{NW}$ & $\mathrm{PbS}$ & $\mathrm{Au}$ & 5.4 & 59 \\
\hline $\mathrm{TiO}_{2} \mathrm{NS}$ & $\mathrm{PbSe} / \mathrm{PbS}$ & $\mathrm{Au}$ & 3.9 & 49 \\
\hline $\mathrm{TiO}_{2}$ & $\mathrm{PbS}_{0.9} \mathrm{Se}_{0.1}$ & $\mathrm{Au}$ & 4.2 & 50 \\
\hline $\mathrm{TiO}_{2}$ & $\mathrm{Sb}_{2} \mathrm{~S}_{3}$ & spiro-OMeTAD/Au & 3.1 & 92 \\
\hline $\mathrm{TiO}_{2}$ & $\mathrm{Sb}_{2} \mathrm{~S}_{3}$ & CuSCN/Au & $4.1,3.3,3.7$ & $85,87,89$ \\
\hline $\mathrm{TiO}_{2}$ & $\mathrm{Sb}_{2} \mathrm{~S}_{3}$ & P3HT/Au & $3.9,4 \cdot 9,5.1$ & $14,90,94$ \\
\hline $\mathrm{TiO}_{2}$ & $\mathrm{Sb}_{2} \mathrm{~S}_{3}$ & PCPDTBT/Au & 6.3 & 15 \\
\hline $\mathrm{TiO}_{2}$ & $\mathrm{CH}_{3} \mathrm{NH}_{3} \mathrm{PbBr}_{3}$ & PCBTDPP/Au & 3.0 & 106 \\
\hline $\mathrm{Al}_{2} \mathrm{O}_{3}$ & $\mathrm{CH}_{3} \mathrm{NH}_{3} \mathrm{PbBr}_{3}$ & $\mathrm{PCBM} / \mathrm{Au}$ & 0.7 & 108 \\
\hline $\mathrm{TiO}_{2} \mathrm{NW}$ & $\mathrm{CH}_{3} \mathrm{NH}_{3} \mathrm{Pbl}_{3}$ & Spiro-OMeTAD/Au & 4.2 & 107 \\
\hline $\mathrm{TiO}_{2} \mathrm{NW}$ & $\mathrm{CH}_{3} \mathrm{NH}_{3} \mathrm{Pbl}_{2} \mathrm{Br}$ & Spiro-OMeTAD/Au & 4.8 & 107 \\
\hline $\mathrm{TiO}_{2}$ & $\mathrm{CH}_{3} \mathrm{NH}_{3} \mathrm{Pbl}_{3}$ & PCPDTBT/Au & 5.3 & 103 \\
\hline $\mathrm{TiO}_{2} \mathrm{NS}$ & $\mathrm{CH}_{3} \mathrm{NH}_{3} \mathrm{Pbl}_{3}$ & $\mathrm{Au}$ & 5.5 & 114 \\
\hline $\mathrm{TiO}_{2}$ & $\mathrm{CH}_{3} \mathrm{NH}_{3} \mathrm{Pbl}_{3}$ & PCBTDPP/Au & 5.5 & 106 \\
\hline $\mathrm{TiO}_{2}$ & $\mathrm{CH}_{3} \mathrm{NH}_{3} \mathrm{Pbl}_{3}$ & P3HT/Au & 6.7 & 103 \\
\hline $\mathrm{TiO}_{2} \mathrm{NR}$ & $\mathrm{CH}_{3} \mathrm{NH}_{3} \mathrm{Pbl}_{3}$ & Spiro-OMeTAD/Au & 9.4 & 104 \\
\hline $\mathrm{TiO}_{2}$ & $\mathrm{CH}_{3} \mathrm{NH}_{3} \mathrm{Pbl}_{3}$ & Spiro-OMeTAD/Ag & 8.5 & 105 \\
\hline $\mathrm{TiO}_{2}$ & $\mathrm{CH}_{3} \mathrm{NH}_{3} \mathrm{Pbl}_{3}$ & PTAA/Au & 12.0 & 103 \\
\hline $\mathrm{TiO}_{2}$ & $\mathrm{CH}_{3} \mathrm{NH}_{3} \mathrm{~Pb}\left(\mathrm{I}_{1-x} \mathrm{Br}_{\mathrm{x}}\right)_{3}$ & PTAA/Au & 12.3 & 3 \\
\hline $\mathrm{TiO}_{2}$ & $\mathrm{CH}_{3} \mathrm{NH}_{3} \mathrm{Pbl}_{3}$ & Spiro-OMeTAD/Au & $9.7,15.0$ & 1,12 \\
\hline $\mathrm{Al}_{2} \mathrm{O}_{3}$ & $\mathrm{CH}_{3} \mathrm{NH}_{3} \mathrm{Pbl}_{2} \mathrm{Cl}$ & Spiro-OMeTAD/Ag & 10.9 & 11 \\
\hline $\mathrm{Al}_{2} \mathrm{O}_{3}$ & $\mathrm{CH}_{3} \mathrm{NH}_{3} \mathrm{Pbl}_{3-\mathrm{x}} \mathrm{Cl}_{\mathrm{x}}$ & Spiro-OMeTAD/Ag & 12.3 & 2 \\
\hline $\mathrm{ZrO}_{2}$ & $\mathrm{CH}_{3} \mathrm{NH}_{3} \mathrm{Pbl}_{3}$ & Spiro-OMeTAD & 10.8 & 110 \\
\hline
\end{tabular}

Abbreviations: NP, nanopillars; NR, nanorods; NS, nanosheets; NW, nanowires. 


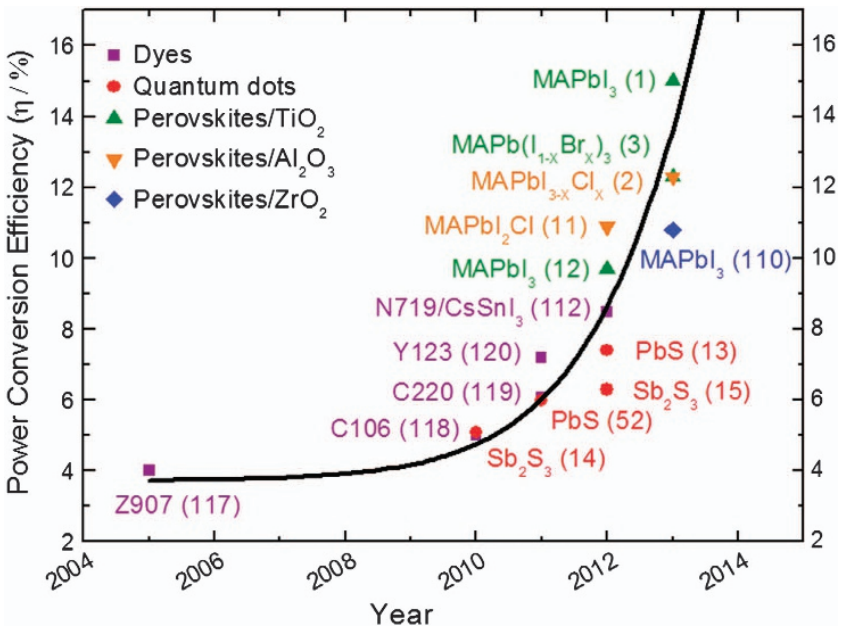

Figure 19 Efficiency progress charts of all-solid-state DSSCs, QDSCs and perovskite-based SCs developed during 2005-2013. The solid curve represents the average progress trend with the corresponding references quoted in parentheses. The symbol MA represents perovskites with an organic component of $\mathrm{CH}_{3} \mathrm{NH}_{3}$.

ruthenium or porphyrin dyes with efficiencies of power conversion exceeding $12 \%,{ }^{9,10}$ but these traditional DSSCs have durability problems due to (i) instability of the organic sensitizers and (ii) leakage of the devices containing typical liquid-type electrolytes. To solve these critical problems for DSSCs, various inorganic light harvesters have been intensively developed, in combination with hole-conducting materials of organic or polymer type. Therefore, herein we have reviewed inorganic nanomaterials of two types-metal chalcogenides and halide perovskites-as prospective photosensitizers or light absorbers for hybrid mesoscopic solar cells. A summary of the photovoltaic performances of these inorganic photosensitizers in liquid-type electrolytes appears in Table 1 . The power conversion efficiencies of these devices are randomly distributed from 2 to $6 \%$, and their performances are much poorer than those of the liquid-type DSSCs, according to the comparison shown in Figure 18. Although a large photocurrent was reported for a mercury-doped PbSsensitized SC $\left(J_{\mathrm{SC}}=30 \mathrm{~mA} \mathrm{~cm}^{-2}\right),{ }^{18}$ its poor photovoltage is a typical problem for QD-based solar cells. All-solid-state mesoscopic solar cells have been rapidly developing and have shown astonishing progress in their device performance during the period 2012-2013. A summary of the photovoltaic performances of all-solid-state quantum-dot-sensitized solar cells and lead halide perovskite-based solar cells appears in Table 2; their progress trends are demonstrated in Figure 19. The first all-solid-state DSSC was reported in 1998 with a small PCE $(0.74 \%)$; it had a ruthenium complex dye and an organic HTM (spiro-OMeTAD) as a solidstate electrolyte. ${ }^{116}$ The device efficiency of an all-solid-state DSSC quickly rose to $4.0 \%$ in 2005 (Z907) ${ }^{117}$ and to $5.0 \%$ in 2010 (C106). ${ }^{118}$ In 2011, two metal-free organic dyes, C220 ${ }^{119}$ and $\mathrm{Y} 123,{ }^{120}$ showed promising performances for all-solid-state devices, attaining efficiencies of 6.1 and $7.2 \%$, respectively. Since 2010, metal chalcogenide QDs have played an important role as suitable sensitizers for solid-state mesoscopic $\mathrm{TiO}_{2}$ solar cells. The two most promising QD sensitizers are $\mathrm{PbS}$ and $\mathrm{Sb}_{2} \mathrm{~S}_{3}$; the PCEs of these QDSCs reached $\sim 7 \%$ in 2012. The most remarkable advancement in the development of all-solid-state mesoscopic solar cells was the discovery of light harvesters of the perovskite type. As Figure 19 shows, the development of perovskite-based solar cells has progressed expeditiously, with achieved PCEs of $10 \%^{11,12}$ in 2012 , followed by $12 \%^{2,3,103}$ and then $15 \%^{1}$ in 2013 . Such striking and rapid progress in the development of organicinorganic hybrid photovoltaic devices indicates the threshold of a new era for the commercialization of all-solid-state mesoscopic solar cells in the near future.

\section{ACKNOWLEDGEMENTS}

The National Science Council of Taiwan and the Ministry of Education of Taiwan, under the ATU program, provided support for this project.

1 Burschka, J., Pellet, N., Moon, S. J., Humphry-Baker, R., Gao, P., Nazeeruddin, M. K \& Grätzel, M Sequential deposition as a route to high-performance perovskitesensitized solar cells. Nature 499, 316-319 (2013).

2 Ball, J. M., Lee, M. M., Hey, A. \& Snaith, H. J. Low-temperature processed mesosuperstructured to thin-film perovskite solar cells. Energy Environ. Sci. 6 1739-1743 (2013).

3 Noh, J. H., Im, S. H., Heo, J. H., Mandal, T. N. \& Seok, S. I. Chemical management for colorful, efficient, and stable inorganic-organic hybrid nanostructured solar cells. Nano Lett. 13, 1764-1769 (2013).

4 Kamat, P. V. Quantum dot solar cells. The next big thing in photovoltaics. J. Phys. Chem. Lett. 4, 908-918 (2013).

5 Ruhle, S., Shalom, M. \& Zaban, A Quantum-dot-sensitized solar cells. Chem PhysChem 11, 2290-2304 (2010).

6 Grätzel, M., Janssen, R. A., Mitzi, D. B. \& Sargent, E. H. Materials interface engineering for solution-processed photovoltaics. Nature 488, 304-312 (2012).

7 Grätzel, M. Recent advances in sensitized mesoscopic solar cells. Acc. Chem. Res. 42, 1788-1798 (2009).

8 O'Regan, B. \& Grätzel, M. A low-cost, high efficiency solar cell based on dyesensitized colloidal $\mathrm{TiO}_{2}$ films. Nature 353, 737-740 (1991).

9 Yella, A., Lee, H. W., Tsao, H. N., Yi, C., Chandiran, A. K., Nazeeruddin, M. K., Diau, E. W. Yeh, C. Y., Zakeeruddin, S. M. \& Gratzel, M. Porphyrin-sensitized solar cells with cobalt (II/ III)-based redox electrolyte exceed 12 percent efficiency. Science 334, 629-634 (2011).

10 Li, L. L. \& Diau, E. W. Porphyrin-sensitized solar cells. Chem. Soc. Rev. 42, 291-304 (2013).

11 Lee, M. M., Teuscher, J., Miyasaka, T., Murakami, T. N. \& Snaith, H. J. Efficient hybrid solar cells based on meso-superstructured organometal halide perovskites. Science 338, 643-647 (2012).

12 Kim, H. S., Lee, C. R., Im, J. H., Lee, K. B., Moehl, T., Marchioro, A., Moon, S. J., Humphry-Baker, R., Yum, J. H., Moser, J. E., Gratzel, M. \& Park, N. G. Lead iodide perovskite sensitized all-solid-state submicron thin film mesoscopic solar cell with efficiency exceeding 9\%. Sci. Rep 2, 591 (2012).

13 Ip, A. H., Thon, S. M., Hoogland, S., Voznyy, O., Zhitomirsky, D., Debnath, R., Levina, L., Rollny, L. R., Carey, G. H., Fischer, A., Kemp, K. W., Kramer, I. J., Ning, Z., Labelle, A. J., Chou, K. W., Amassian, A. \& Sargent, E. H. Hybrid passivated colloidal quantum dot solids. Nature Nanotech 7, 577-582 (2012).

14 Chang, J. A., Rhee, J. H., Im, S. H., Lee, Y. H., Kim, H. J., Seok, S. I., Nazeeruddin, M. K. \& Gratzel, M. High-performance nanostructured inorganic-organic heterojunction solar cells. Nano Lett. 10, 2609-2612 (2010).

15 Chang, J. A., Im, S. H., Lee, Y. H., Kim, H. J., Lim, C. S., Heo, J. H. \& Seok, S. I. Panchromatic photon-harvesting by hole-conducting materials in inorganic-organic heterojunction sensitized-solar cell through the formation of nanostructured electron channels. Nano Lett. 12, 1863-1867 (2012).

16 Nozik, A. J. Multiple exciton generation in semiconductor quantum dots. Chem. Phys. Lett. 457, 3-11 (2008).

17 Semonin, O. E., Luther, J. M., Choi, S., Chen, H. Y., Gao, J., Nozik, A. J. \& Beard, M. C. Peak external photocurrent quantum efficiency exceeding $100 \%$ via MEG in a quantum dot solar cell. Science 334, 1530-1533 (2011).

18 Lee, J. W., Son, D. Y., Ahn, T. K., Shin, H. W., Kim, I. Y., Hwang, S. J., Ko, M. J., Sul, S. Han, H. \& Park, N. G. Quantum-dot-sensitized solar cell with unprecedentedly high photocurrent. Sci. Rep. 3, 1050 (2013).

19 Sun, W. T., Yu, Y., Pan, H.-Y., Gao, X.-F., Chen, Q. \& Peng, L. M. CdS quantum dots sensitized $\mathrm{TiO}_{2}$ nanotube-array photoelectrodes. J. Am. Chem. Soc. 130, 1124-1125 (2008).

20 Ren, S., Chang, L. Y., Lim, S. K., Zhao, J., Smith, M., Zhao, N., Bulovic, V., Bawendi, M. \& Gradecak, S. Inorganic-organic hybrid solar cell: bridging quantum dots to conjugated polymer nanowires. Nano Lett. 11, 3998-4002 (2011).

21 Lee, H., Leventis, H. C., Moon, S.-J., Chen, P., Ito, S., Haque, S. A., Torres, T. Nüesch, F., Geiger, T., Zakeeruddin, S. M., Grätzel, M. \& Nazeeruddin, M. K. PbS and CdS quantum dot-sensitized solid-state solar cells: 'old concepts, new results'. Adv. Funct. Mater. 19, 2735-2742 (2009).

22 Brennan, T. P., Ardalan, P., Lee, H.-B.-R., Bakke, J. R., Ding, I. K., McGehee, M. D. \& Bent, S. F. Atomic layer deposition of cds quantum dots for solid-state quantum dot sensitized solar cells. Adv. Energy Mater. 1, 1169-1175 (2011). 
23 Dowland, S., Lutz, T., Ward, A., King, S. P., Sudlow, A., Hill, M. S., Molloy, K. C. \& Haque, S. A. Direct growth of metal sulfide nanoparticle networks in solid-state polymer films for hybrid inorganic-organic solar cells. Adv. Mater. 23, 2739-2744 (2011).

24 Qian, J., Liu, Q. S., Li, G., Jiang, K. J., Yang, L. M. \& Song, Y. P3HT as hole transport material and assistant light absorber in CdS quantum dots-sensitized solid-state solar cells. Chem. Comm. 47, 6461-6463 (2011).

25 Balis, N., Dracopoulos, V., Stathatos, E., Boukos, N. \& Lianos, P. A solid-state hybrid solar cell made of $\mathrm{nc}^{-\mathrm{TiO}_{2}}$, CdS quantum dots, and P3HT with 2-amino-1methylbenzimidazole as an interface modifier. J. Phys. Chem. C 115, 10911-10916 (2011).

26 Diguna, L. J., Shen, Q., Kobayashi, J. \& Toyoda, T. High efficiency of CdSe quantum-dot-sensitized $\mathrm{TiO}_{2}$ inverse opal solar cells. Appl. Phys. Lett. 91, 023116 (2007).

27 Celik, D., Krueger, M., Veit, C., Schleiermacher, H. F., Zimmermann, B., Allard, S., Dumsch, I., Scherf, U., Rauscher, F. \& Niyamakom, P. Performance enhancement of CdSe nanorod-polymer based hybrid solar cells utilizing a novel combination of postsynthetic nanoparticle surface treatments. Solar Energy Mater. Solar Cells 98, 433-440 (2012)

28 Lee, Y. H., Im, S. H., Chang, J. A., Lee, J.-H. \& Seok, S. I. CdSe-sensitized inorganicorganic heterojunction solar cells: the effect of molecular dipole interface modification and surface passivation. Org. Electron. 13, 975-979 (2012).

29 Shalom, M., Buhbut, S., Tirosh, S. \& Zaban, A Design rules for high-efficiency quantum-dot-sensitized solar cells: a multilayer approach. J. Phys. Chem. Lett. 3 , 2436-2441 (2012).

30 Tachan, Z., Hod, I., Shalom, M., Grinis, L. \& Zaban, A The importance of the $\mathrm{TiO}_{2} /$ quantum dots interface in the recombination processes of quantum dot sensitized solar cells. Phys. Chem. Chem. Phys. 15, 3841-3845 (2013).

31 Barcelo, I., Campina, J. M., Lana-Villarreal, T. \& Gomez, R. A solid-state CdSe quantum dot sensitized solar cell based on a quaterthiophene as a hole transporting material. Phys. Chem. Chem. Phys. 14, 5801-5807 (2012).

32 Philias, J.-M. \& Marsan, B. All-solid-state photoelectrochemical cell based on a polymer electrolyte containing a new transparent and highly electropositive redox couple. Electrochim. Acta 44, 2915-2926 (1999).

33 Kniprath, R., Rabe, J. P., McLeskey, J. T., Wang, D. \& Kirstein, S. Hybrid photovoltaic cells with II-VI quantum dot sensitizers fabricated by layer-by-layer deposition of water-soluble components. Thin Solid Films 518, 295-298 (2009).

34 Chen, Z., Zhang, H., Yu, W., Li, Z., Hou, J., Wei, H. \& Yang, B. Inverted hybrid sola cells from aqueous materials with a PCE of 3.61\%. Adv. Energy Mater. 3, 433-437 (2013).

35 Yue, G., Wu, J., Xiao, Y., Lin, J., Huang, M., Lan, Z. \& Fan, L. CdTe quantum dotssensitized solar cells featuring PCBM/P3HT as hole transport material and assistant sensitizer provide 3.40\% efficiency. Electrochim. Acta 85, 182-186 (2012).

36 Chen, H. C., Lai, C. W., Wu, I. C., Pan, H. R., Chen, I. W., Peng, Y. K., Liu, C. L., Chen, C. H. \& Chou, P. T. Enhanced performance and air stability of $3.2 \%$ hybrid solar cells: how the functional polymer and $\mathrm{CdTe}$ nanostructure boost the solar cel efficiency. Adv. Mater. 23, 5451-5455 (2011).

37 Sun, S., Liu, H., Gao, Y., Qin, D. \& Chen, J. Controlled synthesis of CdTe nanocrystals for high performanced Schottky thin film solar cells. J. Mater. Chem. 22, 19207 (2012)

38 Olson, J. D., Rodriguez, Y. W., Yang, L. D., Alers, G. B. \& Carter, S. A. CdTe Schottky diodes from colloidal nanocrystals. Appl. Phys. Lett 96, 242103 (2010).

39 Lee, Y.-L. \& Lo, Y.-S. Highly efficient quantum-dot-sensitized solar cell based on cosensitization of CdS/CdSe. Adv. Funct. Mater. 19, 604-609 (2009)

40 MacDonald, B. I., Martucci, A., Rubanov, S., Watkins, S. E., Mulvaney, P. \& Jasieniak, J. J. Layer-by-layer assembly of sintered $\mathrm{CdSe}_{\mathrm{x}} \mathrm{Te}_{1-\mathrm{x}}$ nanocrystal solar cells. ACS Nano 6, 5995-6004 (2012)

41 Itzhakov, S., Shen, H., Buhbut, S., Lin, H. \& Oron, D. Type-II quantum-dot-sensitized solar cell spanning the visible and near-infrared spectrum. J. Phys. Chem. C doi:10.1021/jp312190x (2013) (in press).

42 Yu, Z., Zhang, Q., Qin, D., Luo, Y., Li, D., Shen, Q., Toyoda, T. \& Meng, Q. Highly efficient quasi-solid-state quantum-dot-sensitized solar cell based on hydrogel electrolytes. Electrochem. Comm. 12, 1776-1779 (2010).

43 Karageorgopoulos, D., Stathatos, E. \& Vitoratos, E. Thin $\mathrm{ZnO}$ nanocrystalline films for efficient quasi-solid state electrolyte quantum dot sensitized solar cells. J. Power Sour. 219, 9-15 (2012).

44 Santra, P. K. \& Kamat, P. V. Mn-doped quantum dot sensitized solar cells: a strategy to boost efficiency over 5\%. J. Am. Chem. Soc. 134, 2508-2511 (2012).

45 Santra, P. K. \& Kamat, P. V. Tandem-layered quantum dot solar cells: tuning the photovoltaic response with luminescent ternary cadmium chalcogenides. J. Am. Chem. Soc. 135, 877-885 (2013)

46 Chi, C.-F., Chen, P., Lee, Y.-L., Liu, I. P., Chou, S.-C., Zhang, X.-L. \& Bach, U. Surface modifications of $\mathrm{CdS} / \mathrm{CdSe}$ co-sensitized $\mathrm{TiO}_{2}$ photoelectrodes for solid-state quantum-dot-sensitized solar cells. J. Mater. Chem. 21, 17534 (2011).

47 Ma, W., Swisher, S. L., Ewers, T., Engel, J., Ferry, V. E., Atwater, H. A. \& Alivisatos, A. P. Photovoltaic performance of ultrasmall pbse quantum dots. ACS Nano 5, 8140-8147 (2011)

48 Choi, J. J., Lim, Y. F., Santiago-Berrios, M. B., Oh, M., Hyun, B. R., Sun, L., Bartnik, A. C., Goedhart, A., Malliaras, G. G., Abruna, H. D., Wise, F. W. \& Hanrath, T. PbSe nanocrystal excitonic solar cells. Nano Lett. 9, 3749-3755 (2009).

49 Etgar, L., Yanover, D., Čapek, R. K., Vaxenburg, R., Xue, Z., Liu, B., Nazeeruddin, M. K., Lifshitz, E. \& Gratzel, M Core/shell PbSe/PbS QDs TiO 2 heterojunction solar cell. Adv. Funct. Mater. 23, 2736-2741 (2013).
50 Zhai, G., Church, C. P., Breeze, A. J., Zhang, D., Alers, G. B. \& Carter, S. A. Quantum dot $\mathrm{PbS}_{0.9} \mathrm{Se}_{0.1} / \mathrm{TiO}_{2}$ heterojunction solar cells. Nanotechnology 23, 405401 (2012)

51 Ning, Z., Ren, Y., Hoogland, S., Voznyy, O., Levina, L., Stadler, P., Lan, X., Zhitomirsky, D. \& Sargent, E. H. All-inorganic colloidal quantum dot photovoltaics employing solution-phase halide passivation. Adv. Mater. 24, 6295-6299 (2012).

52 Tang, J., Kemp, K. W., Hoogland, S., Jeong, K. S., Liu, H., Levina, L., Furukawa, M., Wang, X., Debnath, R., Cha, D., Chou, K. W., Fischer, A., Amassian, A., Asbury, J. B. \& Sargent, E. H. Colloidal-quantum-dot photovoltaics using atomic-ligand passivation. Nature Mater 10, 765-771 (2011).

53 Jeong, K. S., Tang, J., Liu, H., Kim, J., Schaefer, A. W., Kemp, K., Levina, L., Wang, X., Hoogland, S., Debnath, R., Brzozowski, L., Sargent, E. H. \& Asbury, J. B. Enhanced mobility-lifetime products in PbS colloidal quantum dot photovoltaics. ACS Nano 6 , 89-99 (2012).

54 Tang, J., Liu, H., Zhitomirsky, D., Hoogland, S., Wang, X., Furukawa, M., Levina, L. \& Sargent, E. H. Quantum junction solar cells. Nano Lett. 12, 4889-4894 (2012).

55 Song, T., Zhang, F., Lei, X., Xu, Y., Lee, S. \& Sun, B. Core-shell structured photovoltaic devices based on $\mathrm{PbS}$ quantum dots and silicon nanopillar arrays. Nanoscale 4, 1336-1343 (2012).

56 Kramer, I. J., Zhitomirsky, D., Bass, J. D., Rice, P. M., Topuria, T., Krupp, L., Thon, S. M., Ip, A. H., Debnath, R., Kim, H. C. \& Sargent, E. H. Ordered nanopillar structured electrodes for depleted bulk heterojunction colloidal quantum dot solar cells. Adv. Mater. 24, 2315-2319 (2012)

57 Kim, S., Im, S. H., Kang, M., Heo, J. H., Seok, S. I., Kim, S. W., Mora-Sero, I. \& Bisquert, J. Air-stable and efficient inorganic-organic heterojunction solar cells using $\mathrm{PbS}$ colloidal quantum dots co-capped by 1-dodecanethiol and oleic acid. Phys. Chem. Chem. Phys. 14, 14999-15002 (2012).

58 Im, S. H., Kim, H.-j., Kim, S. W., Kim, S.-W. \& Seok, S. I. All solid state multiply layered PbS colloidal quantum-dot-sensitized photovoltaic cells. Energy Environ. Sci. 4, 4181-4186 (2011).

59 Xu, F., Benavides, J., Ma, X. \& Cloutier, S. G. Interconnected $\mathrm{TiO}_{2}$ nanowire networks for PbS quantum dot solar cell applications. J. Nanotech. 2012, 6 (2012).

60 Klem, E. J. D., Gregory, C. W., Cunningham, G. B., Hall, S., Temple, D. S. \& Lewis, J. S. Planar $\mathrm{PbS}$ quantum dot/ $\mathrm{C}_{60}$ heterojunction photovoltaic devices with $5.2 \%$ power conversion efficiency. Appl. Phys. Lett. 100, 173109 (2012).

61 Rath, A. K., Bernechea, M., Martinez, L., Arquer, F. P. G., Osmond, J. \& Konstantatos, G. Solution-processed inorganic bulk nano-heterojunctions and their application to solar cells. Nature Photon 6, 529-534 (2012)

62 Etgar, L., Zhang, W., Gabriel, S., Hickey, S. G., Nazeeruddin, M. K., Eychmuller, A., Liu, B. \& Gratzel, M. High efficiency quantum dot heterojunction solar cell using anatase (001) $\mathrm{TiO}_{2}$ nanosheets. Adv. Mater. 24, 2202-2206 (2012).

63 Gao, J., Perkins, C. L., Luther, J. M., Hanna, M. C., Chen, H. Y., Semonin, O. E., Nozik, A. J., Ellingson, R. J. \& Beard, M. C. n-Type transition metal oxide as a hole extraction layer in PbS quantum dot solar cells. Nano Lett. 11, 3263-3266 (2011)

64 Park, H., Chang, S., Jean, J., Cheng, J. J., Araujo, P. T., Wang, M., Bawendi, M. G., Dresselhaus, M. S., Bulovic, V., Kong, J. \& Gradecak, S. Graphene cathode-based ZnO nanowire hybrid solar cells. Nano Lett. 13, 233-239 (2013).

65 Brown, P. R., Lunt, R. R., Zhao, N., Osedach, T. P., Wanger, D. D., Chang, L. Y., Bawendi, M. G. \& Bulovic, V. Improved current extraction from $\mathrm{ZnO} / \mathrm{PbS}$ quantum dot heterojunction photovoltaics using a $\mathrm{MoO}_{3}$ interfacial layer. Nano Lett. 11 , 2955-2961 (2011).

66 Chen, H.-Y., Hou, J., Dayal, S., Huo, L., Kopidakis, N., Beard, M. C. \& Luther, J. M. A p-Type quantum dot/organic donor:acceptor solar-cell structure for extended spectral response. Adv. Energy Mater. 1, 528-533 (2011).

67 Zhang, Y., Li, Z., Ouyang, J., Tsang, S.-W., Lu, J., Yu, K., Ding, J. \& Tao, Y. Hole transfer from $\mathrm{PbS}$ nanocrystal quantum dots to polymers and efficient hybrid solar cells utilizing infrared photons. Org. Electron. 13, 2773-2780 (2012).

68 Zhou, N., Chen, G., Zhang, X., Cheng, L., Luo, Y., Li, D. \& Meng, Q. Highly efficient $\mathrm{PbS} / \mathrm{CdS}$ co-sensitized solar cells based on photoanodes with hierarchical pore distribution. Electrochem. Comm. 20, 97-100 (2012).

69 Wang, D., Baral, J. K., Zhao, H., Gonfa, B. A., Truong, V.-V., El Khakani, M. A., Izquierdo, R. \& Ma, D. Controlled fabrication of PbS quantum-dot/carbon-nanotube nanoarchitecture and its significant contribution to near-infrared photon-to-current conversion. Adv. Funct. Mater. 21, 4010-4018 (2011).

70 Ehrler, B., Wilson, M. W., Rao, A., Friend, R. H. \& Greenham, N. C. Singlet exciton fission-sensitized infrared quantum dot solar cells. Nano Lett. 12, 1053-1057 (2012)

71 Lin, C.-Y., Teng, C.-Y., Li, T.-L., Lee, Y.-L. \& Teng, H. Photoactive p-type PbS as a counter electrode for quantum dot-sensitized solar cells. J. Mater. Chem. A 1, 1155-1162 (2013)

72 Yang, Y., Zhu, L., Sun, H., Huang, X., Luo, Y., Li, D. \& Meng, Q. Composite counter electrode based on nanoparticulate $\mathrm{PbS}$ and carbon black: towards quantum dotsensitized solar cells with both high efficiency and stability. ACS Appl. Mater. Interfaces 4, 6162-6168 (2012).

73 Sung, S. D., Lim, I., Kang, P., Lee, C. \& Lee, W. I. Design and development of highly efficient $\mathrm{PbS}$ quantum dot-sensitized solar cells working in an aqueous polysulfide electrolyte. Chem. Comm. 49, 6054-6056 (2013).

74 Yu, K., Ouyang, J., Zhang, Y., Tung, H. T., Lin, S., Nagelkerke, R. A., Kingston, D., Wu, X., Leek, D. M., Wilkinson, D., Li, C., Chen, I. G. \& Tao, Y. Low-temperature noninjection approach to homogeneously-alloyed $\mathrm{PbSe}_{x} \mathrm{~S}_{1-x}$ colloidal nanocrystals for photovoltaic applications. ACS Appl. Mater. Interfaces 3, 1511-1520 (2011). 
75 Ma, W., Luther, J. M., Zheng, H., Wu, Y. \& Alivisatos, A. P. Photovoltaic devices employing ternary $\mathrm{PbS}_{\mathrm{x}} \mathrm{Se}_{1-\mathrm{x}}$ nanocrystals. Nano Lett. 9, 1699-1703 (2009).

76 Ouyang, J., Schuurmans, C., Zhang, Y., Nagelkerke, R., Wu, X., Kingston, D., Wang, Z. Y. Wilkinson, D., Li, C., Leek, D. M., Tao, Y. \& Yu, K. Low-temperature approach to high-yield and reproducible syntheses of high-quality small-sized PbSe colloidal nanocrystals for photovoltaic applications. ACS Appl. Mater. Interfaces 3, 553-565 (2011).

77 Kuo, C.-Y., Su, M.-S., Ku, C.-S., Wang, S.-M., Lee, H.-Y. \& Wei, K.-H. Ligands affect the crystal structure and photovoltaic performance of thin films of PbSe quantum dots. J. Mater. Chem. 21, 11605-11612 (2011).

78 Kuo, C.-Y., Su, M.-S., Hsu, Y.-C., Lin, H.-N. \& Wei, K.-H. An organic hole transport layer enhances the performance of colloidal $\mathrm{PbSe}$ quantum dot photovoltaic devices. Adv. Funct. Mater. 20, 3555-3560 (2010).

79 Liu, Y., Gibbs, M., Perkins, C. L., Tolentino, J., Zarghami, M. H., Bustamante, J. Jr. \& Law, M. Robust, functional nanocrystal solids by infilling with atomic layer deposition. Nano Lett. 11, 5349-5355 (2011).

80 Benehkohal, N. P., González-Pedro, V., Boix, P. P., Chavhan, S., Tena-Zaera, R. Demopoulos, G. P. \& Mora-Seró, I. Colloidal PbS and PbSeS quantum dot sensitized solar cells prepared by electrophoretic deposition. J. Phys. Chem. C 116, 16391-16397 (2012).

81 Cui, D., Xu, J., Zhu, T., Paradee, G., Ashok, S. \& Gerhold, M. Harvest of near infrared light in PbSe nanocrystal-polymer hybrid photovoltaic cells. Appl. Phys. Lett. 88, 183111 (2006).

82 Tan, Z., Zhu, T., Thein, M., Gao, S., Cheng, A., Zhang, F., Zhang, C., Su, H., Wang, J., Henderson, R., Hahm, J.-i., Yang, Y. \& Xu, J. Integration of planar and bulk heterojunctions in polymer/nanocrystal hybrid photovoltaic cells. Appl. Phys. Lett. 95, 063510 (2009).

83 Nam, M., Kim, S., Kim, T., Kim, S.-W. \& Lee, K.-K. Broadband energy-harvesting hybrid solar cells employing nanocomposites of polythiophene:ternary PbSSe nanocrystals. Appl. Phys. Lett. 99, 233115 (2011).

84 Messina, S., Nair, M. T. S. \& Nair, P. K. Antimony sulfide thin films in chemically deposited thin film photovoltaic cells. Thin Solid Films 515, 5777-5782 (2007)

85 Itzhaik, Y., Niitsoo, O., Page, M. \& Hodes, G. Sb $2 \mathrm{~S}_{3}$-sensitized nanoporous $\mathrm{TiO}_{2}$ solar cells. J. Phys. Chem. C 113, 4254-4256 (2009).

86 Patrick, C. E. \& Giustino, F. Structural and electronic properties of semiconductorsensitized solar-cell interfaces. Adv. Funct. Mater. 21, 4663-4667 (2011).

87 Nezu, S., Larramona, G., Choné, C., Jacob, A., Delatouche, B., Péré, D. \& Moisan, C. Light soaking and gas effect on nanocrystalline $\mathrm{TiO}_{2} / \mathrm{Sb}_{2} \mathrm{~S}_{3} / \mathrm{CuSCN}$ photovoltaic cells following extremely thin absorber concept. J. Phys. Chem. C 114, 6854-6859 (2010).

88 Boix, P. P., Larramona, G., Jacob, A., Delatouche, B., Mora-Seró, I. \& Bisquert, J. Hole transport and recombination in all-solid $\mathrm{Sb}_{2} \mathrm{~S}_{3}$-sensitized $\mathrm{TiO}_{2}$ solar cells using CuSCN as hole transporter. J. Phys. Chem. C 116, 1579-1587 (2012).

89 Tsujimoto, K., Nguyen, D.-C., Ito, S., Nishino, H., Matsuyoshi, H., Konno, A. Kumara, G. R. A. \& Tennakone, $\mathrm{K} \mathrm{TiO}_{2}$ surface treatment effects by $\mathrm{Mg}^{2+}, \mathrm{Ba}^{2+}$, and $\mathrm{Al}^{3+}$ on $\mathrm{Sb}_{2} \mathrm{~S}_{3}$ extremely thin absorber solar cells. J. Phys. Chem. C 116, 13465-13471 (2012).

90 Lim, C. S., Im, S. H., Kim, H. J., Chang, J. A., Lee, Y. H. \& Seok, S. I. Enhancing the device performance of $\mathrm{Sb}_{2} \mathrm{~S}_{3}$-sensitized heterojunction solar cells by embedding $\mathrm{Au}$ nanoparticles in the hole-conducting polymer layer. Phys. Chem. Chem. Phys. 14, 3622-3626 (2012)

91 Boix, P. P., Lee, Y. H., Fabregat-Santiago, F., Im, S. H., Mora-Sero, I., Bisquert, J. \& Seok, S. I. From flat to nanostructured photovoltaics: balance between thickness of the absorber and charge screening in sensitized solar cells. ACS Nano 6, 873-880 (2012).

92 Moon, S. J., Itzhaik, Y., Yum, J. H., Zakeeruddin, S. M., Hodes, G. \& Gratzel, M. $\mathrm{Sb}_{2} \mathrm{~S}_{3}$-based mesoscopic solar cell using an organic hole conductor. J. Phys. Chem Lett. 1, 1524-1527 (2010).

93 O’Mahony, F. T. F., Lutz, T., Guijarro, N., Gómez, R. \& Haque, S. A. Electron and hole transfer at metal oxide/ $\mathrm{Sb}_{2} \mathrm{~S}_{3} /$ spiro-OMeTAD heterojunctions. Energy Environ. Sci. 5, 9760-9764 (2012)

94 Fukumoto, T., Moehl, T., Niwa, Y., Nazeeruddin, M. K., Grätzel, M. \& Etgar, L. Effect of interfacial engineering in solid-state nanostructured $\mathrm{Sb}_{2} \mathrm{~S}_{3}$ heterojunction sola cells. Adv. Energy Mater. 3, 29-33 (2013).

95 Bansal, N., O'Mahony, F. T. F., Lutz, T. \& Haque, S. A. Solution processed polymer-inorganic semiconductor solar cells employing Sb2S3 as a light harvesting and electron transporting material. Adv. Energy Mater. 3, 986-990 (2013).

96 Messina, S., Nair, M. T. S. \& Nair, P. K. Solar cells with $\mathrm{Sb}_{2} \mathrm{~S}_{3}$ absorber films. Thin Solid Films 517, 2503-2507 (2009).

97 Messina, S., Nair, M. T. S. \& Nair, P. K. Antimony selenide absorber thin films in all-chemically deposited solar cells. J. Electrochem. Soc. 156, H327-H332 (2009).

98 Barrios-Salgado, E., Nair, M. T. S., Nair, P. K. \& Zingaro, R. A. Chemically deposited thin films of PbSe as an absorber component in solar cell structures. Thin Solid Films 519, 7432-7437 (2011).
99 Guijarro, N., Lutz, T., Lana-Villarreal, T., O’Mahony, F., Gómez, R. \& Haque, S. A. Toward antimony selenide sensitized solar cells: efficient charge photogeneration at spiro-OMeTAD/Sb $\mathrm{Se}_{3} /$ metal oxide heterojunctions. J. Phys. Chem. Lett. 3, 1351-1356 (2012)

100 Kojima, A., Teshima, K., Shirai, Y. \& Miyasaka, T. Organometal halide perovskites as visible-light sensitizers for photovoltaic cells. J. Am. Chem. Soc. 131, 6050-6051 (2009).

$101 \mathrm{Im}$, J. H., Lee, C. R., Lee, J. W., Park, S. W. \& Park, N. G. 6.5\% efficient perovskite quantum-dot-sensitized solar cell. Nanoscale 3, 4088-4093 (2011).

102 Im, J. H., Chung, J., Kim, S. J. \& Park, N. G. Synthesis, structure, and photovoltaic property of a nanocrystalline $2 \mathrm{H}$ perovskite-type novel sensitizer $\left(\mathrm{CH}_{3} \mathrm{CH}_{2} \mathrm{NH}_{3}\right) \mathrm{Pbl}_{3}$. Nanoscale Res. Lett. 7, 353 (2012).

$103 \mathrm{Heo}$, J. H., Im, S. H., Noh, J. H., Mandal, T. N., Lim, C.-S., Chang, J. A. Lee, Y. H., Kim, H.-J., Sarkar, A., Nazeeruddin, M. K., Gratzel, M. \& Seok, S. I. Efficient inorganic-organic hybrid heterojunction solar cells containing perovskite compound and polymeric hole conductors. Nature Photon 7, 486-491 (2013).

104 Kim, H. S., Lee, J. W., Yantara, N., Boix, P. P., Kulkarni, S. A., Mhaisalkar, S., Gratzel M. \& Park, N. G. High efficiency solid-state sensitized solar cell-based on submicrometer rutile $\mathrm{TiO}_{2}$ nanorod and $\mathrm{CH}_{3} \mathrm{NH}_{3} \mathrm{Pbl}_{3}$ perovskite sensitizer. Nano Lett. 13, 2412-2417 (2013).

105 Bi, D., Yang, L., Boschloo, G., Hagfeldt, A. \& Johansson, E. M. J. Effect of different hole transport materials on recombination in $\mathrm{CH}_{3} \mathrm{NH}_{3} \mathrm{Pbl}_{3}$ perovskite-sensitized mesoscopic solar cells. J. Phys. Chem. Lett. 4, 1532-1536 (2013).

106 Cai, B., Xing, Y., Yang, Z., Zhang, W.-H. \& Qiu, J. High performance hybrid solar cells sensitized by organolead halide perovskites. Energy Environ. Sci. 6, 1480-1485 (2013).

107 Qiu, J., Qiu, Y., Yan, K., Zhong, M., Mu, C., Yan, H. \& Yang, S. All-solid-state hybrid solar cells based on a new organometal halide perovskite sensitizer and onedimensional $\mathrm{TiO}_{2}$ nanowire arrays. Nanoscale 5, 3245-3248 (2013).

108 Edri, E., Kirmayer, S., Cahen, D. \& Hodes, G. High open-circuit voltage solar cells based on organic-inorganic lead bromide perovskite. J. Phys. Chem. Lett. 4, 897-902 (2013).

109 Abrusci, A., Stranks, S. D., Docampo, P., Yip, H. L., Jen, A. K. \& Snaith, H. J. High performance perovskite-polymer hybrid solar cells via electronic coupling with fullerene monolayers. Nano Lett. 13, 3124-3128 (2013).

110 Bi, D., Häggman, L., Boschloo, G., Yang, L., Johansson, E. M. J. \& Hagfeldt, A. Using two-step deposition technique to prepare perovskite $(\mathrm{CH} 3 \mathrm{NH} 3 \mathrm{~Pb} / 3)$ for thin film solar cells based on $\mathrm{ZrO} 2$ and TiO2 mesostructures. RSC Adv. doi:10.1039/C3RA43228A (in press) (2013).

111 Jeng, J. Y., Chiang, Y. F., Lee, M. H., Peng, S. R., Guo, T. F., Chen, P. \& Wen, T. C. $\mathrm{CH}_{3} \mathrm{NH}_{3} \mathrm{Pbl}_{3}$ perovskite/fullerene planar-heterojunction hybrid solar cells. Adv. Mater. 25, 3727-3732 (2013).

112 Chung, I., Lee, B., He, J., Chang, R. P. \& Kanatzidis, M. G. All-solid-state dyesensitized solar cells with high efficiency. Nature 485, 486-489 (2012).

113 Chen, Z., Wang, J. J., Ren, Y., Yu, C. \& Shum, K. Schottky solar cells based on CsSnl 3 thin-films. Appl. Phys. Lett. 101, 093901 (2012).

114 Etgar, L., Gao, P., Xue, Z., Peng, Q., Chandiran, A. K., Liu, B., Nazeeruddin, M. K. \& Gratzel, M. Mesoscopic $\mathrm{CH}_{3} \mathrm{NH}_{3} \mathrm{Pbl}_{3} / \mathrm{TiO}_{2}$ heterojunction solar cells. J. Am. Chem. Soc. 134, 17396-17399 (2012).

115 Im, S. H., Kim, H.-j., Rhee, J. H., Lim, C.-S. \& Seok, S. I. Performance improvement of $\mathrm{Sb}_{2} \mathrm{~S}_{3}$-sensitized solar cell by introducing hole buffer layer in cobalt complex electrolyte. Energy Environ. Sci. 4, 2799-2802 (2011).

116 Bach, U., Lupo, D., Comte, P., Moser, J. E., Weissortel, F., Salbeck, J., Spreitzer, H. \& Gratzel, M. Solid-state dye-sensitized mesoporous $\mathrm{TiO}_{2}$ solar cells with high photonto-electron conversion efficiencie. Nature 395, 583 (1998).

117 Schmidt-Mende, L., Zakeeruddin, S. M. \& Grätzel, M. Efficiency improvement in solid-state-dye-sensitized photovoltaics with an amphiphilic Ruthenium-dye. Appl. Phys. Lett. 86, 013504 (2005).

118 Wang, M., Liu, J., Cevey-Ha, N.-L., Moon, S.-J., Liska, P., Humphry-Baker, R., Moser, J.-E., Grätzel, C., Wang, P. \& Zakeeruddin, S. M. High efficiency solid-state sensitized heterojunction photovoltaic device. Nano Today 5, 169-174 (2010).

119 Cai, N., Moon, S. J., Cevey-Ha, L., Moehl, T., Humphry-Baker, R., Wang, P., Zakeeruddin, S. M. \& Gratzel, M. An organic D- $\pi-A$ dye for record efficiency solid-state sensitized heterojunction solar cells. Nano Lett. 11, 1452-1456 (2011).

120 Burschka, J., Dualeh, A., Kessler, F., Baranoff, E., Cevey-Ha, N. L., Yi, C. Nazeeruddin, M. K. \& Gratzel, M. Tris(2-(1H-pyrazol-1-yl)pyridine)cobalt(III) as p-type dopant for organic semiconductors and its application in highly efficient solid-state dye-sensitized solar cells. J. Am. Chem. Soc. 133, 18042 18045 (2011)

(c) This work is licensed under a Creative Commons
Attribution 3.0 Unported License. To view a copy of
this license, visit http://creativecommons.org/licenses/by/3.0/
this license, visit http://creativecommons.org/licenses/by/3.0/ 

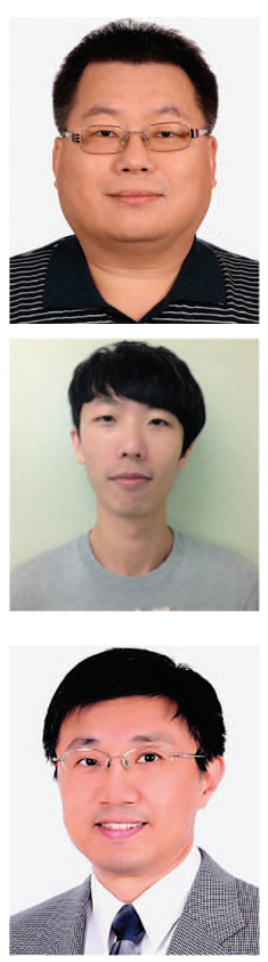

Jae Hui Rhee is a postdoctoral fellow in National Chiao Tung University (NCTU), Taiwan. He received his PhD in Materials Science \& Engineering from the University of Texas at Arlington, TX, USA, in 2004. Before he joined NCTU as a postdoctoral fellow in 2012, he was a postdoctoral researcher in KRICT, South Korea, and NTU, Singapore. He has 5 years of research experience in the synthesis of metal chalcogenide quantum dots and their applications in mesoscopic solar cells. His main research interests include quantum dot solar cells, the synthesis of nanocrystals and photovoltaic device physics.

Chih-Chun Chung is a PhD student in the Department of Applied Chemistry, National Chiao Tung University (NCTU), Taiwan. He obtained his MS degree from NCTU in 2011, with a focus on the fabrication and characterization of doped $\mathrm{TiO}_{2}$ photoanodes for dyesensitized solar cells. Following the research direction for solar cells, he is currently pursuing graduate studies on the subject of all-solidstate mesoscopic solar cells based on prospective light absorbers such as quantum dots and organometal-halide perovskites.

Eric Wei-Guang Diau is a professor at the Department of Applied Chemistry and Science of Molecular Science, National Chiao Tung University (NCTU), Taiwan. He received his PhD in physical chemistry from National Tsing Hua University, Taiwan, in 1991. Before joining NCTU as a faculty member in 2001, he worked as a postdoctoral fellow at Emory University (1993-1995), the University of Queensland (1995-1996) and the California Institute of Technology (1997-2001). He is interested in studying the relaxation dynamics of organic and bio-organic molecules in the condensed phase. His recent research involves the development of novel functional materials for dye-sensitized solar cells (DSSCs) and all-solid-state mesoscopic solar cells, with a focus on the design, synthesis, processing and characterization of light harvesters and nanostructured materials for photovoltaic applications. 